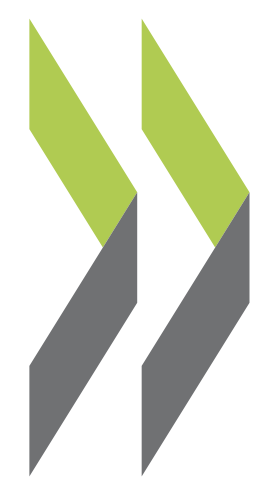

OECD Working Papers on International Investment 2010/02

Foreign State Immunity and Foreign Government Controlled Investors
David Gaukrodger

https://dx.doi.org/10.1787/5km91p0ksqs7-en 


\section{OECD WORKING PAPERS ON INTERNATIONAL INVESTMENT}

The international investment working paper series - including policies and trends and the broader implications of multinational enterprise - is designed to make available to a wide readership selected studies by the OECD Investment Committee, OECD Investment Division staff, or by outside consultants working on OECD Investment Committee projects.

The papers are generally available only in their original language English or French with a summary in the other if available.

The opinions expressed in these papers are the sole responsibility of the author(s) and do not necessarily reflect those of the OECD or the governments of its member countries.

Comment on the series is welcome, and should be sent to either investment@oecd.org or the Investment Division, OECD, 2, rue André Pascal, 75775 PARIS CEDEX 16, France.

OECD WORKING PAPERS ON INTERNATIONAL INVESTMENT

are published on www.oecd.org/daf/investment/workingpapers 


\title{
Abstract \\ FOREIGN STATE IMMUNITY AND FOREIGN GOVERNMENT \\ CONTROLLED INVESTORS
}

\author{
by \\ David Gaukrodger
}

\begin{abstract}
Discussions at the "Freedom of Investment" Roundtables, hosted by the OECD Investment Committee, have stressed that increased investments by foreign State-controlled investors can bring significant benefits to home and host societies, but have also noted that they can raise concerns. This paper examines two principal issues concerning foreign State-controlled investors: whether the doctrine of foreign state immunity may make it difficult for private parties to pursue legitimate claims against them and whether that doctrine creates regulatory enforcement gaps for host countries. Although the restrictive approach to immunity is now widely recognised, important issues, such as whether the financial investment activities of a sovereign wealth fund are commercial or sovereign acts, remain uncertain. In the area of regulation, the paper analyses state policies in the area of tax, competition law and criminal law, and notes key factors that may influence immunity in such cases.
\end{abstract}

JEL classification: F21, F23, G28, H82, K21, K33, K34

Keywords: foreign state immunity; foreign sovereign immunity; state immunity; international investment law; state-controlled investors; foreign government controlled investors; state-owned enterprises; sovereign wealth funds; central banks; competition law; antitrust; taxation; regulation.

Senior Legal Consultant, Investment Division of the OECD Directorate of Financial and Enterprise Affairs (david.gaukrodger@oecd.org). The author expresses his appreciation to the staff of the OECD Investment Division, OECD Centre for Tax Policy and Administration and OECD Competition Division for their comments on an earlier draft of the paper, and to the members and observers of the Roundtable. This paper does not necessarily reflect the views of the OECD or those of its member governments. It cannot be construed as prejudging ongoing or future negotiations or disputes arising under international investment agreements.

Further information on investment-related work at the OECD may be found at www.oecd.org/daf/investment. 


\section{TABLE OF CONTENTS}

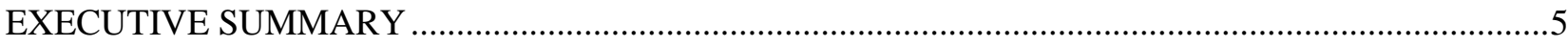

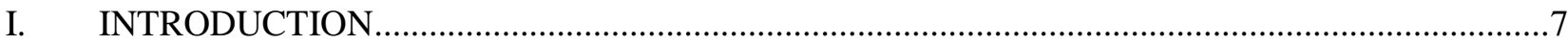

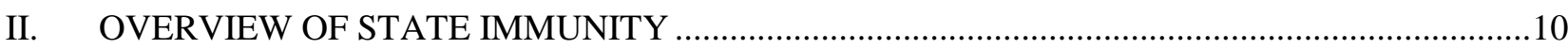

1. International acceptance of a restrictive approach to foreign state immunity...........................10

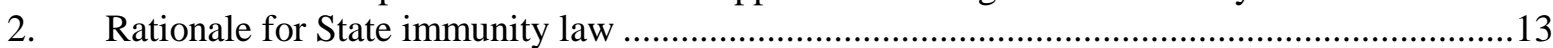

3. The definition of the State and the importance of the legal structure of the foreign

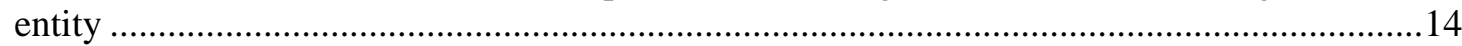

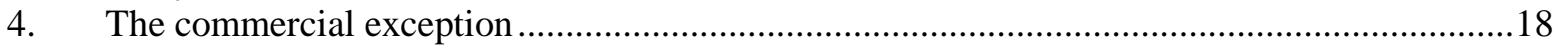

III. FOREIGN CENTRAL BANKS AND REINFORCED IMMUNITY FROM EXECUTION ............24

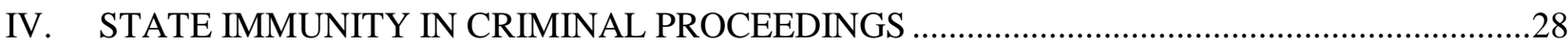

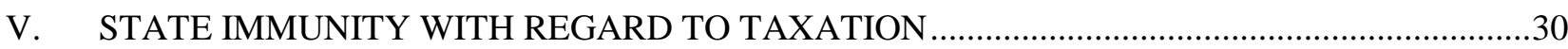

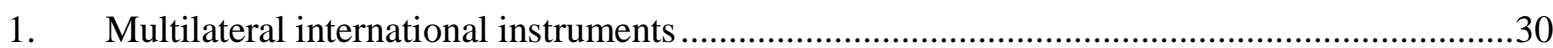

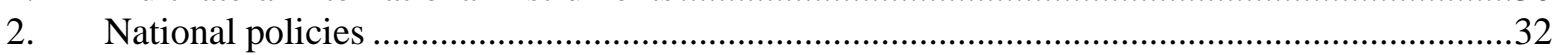

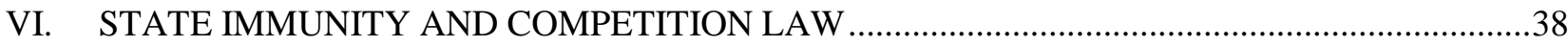

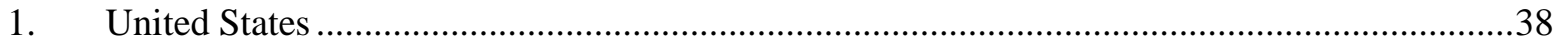

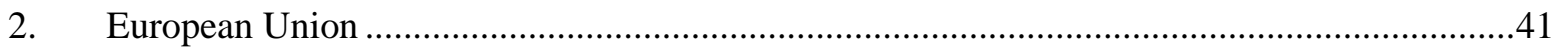

3. The UK government decision to require partial divestment of a Kuwaiti investment

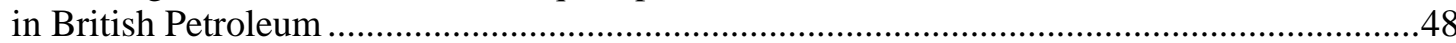

VII. GENERAL CONSIDERATIONS ON THE APPLICATION OF REGULATION TO

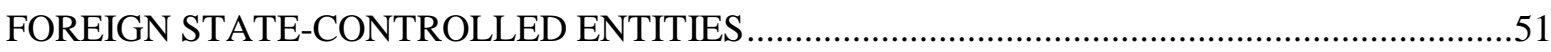

ANNEX 1 Immunity issues and the selection of remedies in a major financial case involving simultaneous criminal, regulatory and civil actions. . .54 


\section{EXECUTIVE SUMMARY}

State-controlled investors - such as sovereign wealth funds and public pension funds - have greatly expanded their foreign investments in recent years. Discussions at the "Freedom of Investment" Roundtables, hosted by the OECD Investment Committee, have stressed the significant benefits that such investments can bring to home and host societies, but have also noted that such investments can raise concerns for host societies. This paper examines two concerns relating to the doctrine of foreign state immunity: whether that doctrine, as applied to foreign State-controlled investors, may make it difficult for private parties to pursue legitimate claims against them, and whether it creates regulatory enforcement gaps for host countries. The purpose of this paper is to help build mutual understanding by recipient countries and State-controlled investors of the issues with a view to facilitating the free flow of investment while addressing concerns about enforcement.

Under the doctrine of foreign state immunity, one State is not subject to the full force of rules applicable in another State; the doctrine bars a national court from adjudicating or enforcing certain claims against foreign States. At one time, States enjoyed "absolute" immunity - all proceedings against foreign states were barred without their consent. As States became more involved in commercial activities, many jurisdictions began to apply a "restrictive" theory of immunity at least in cases brought by private parties. Under the restrictive approach, courts continue to recognise immunity for "sovereign" acts, but deny immunity for "commercial" acts. One purpose of the commercial exception is to protect the legitimate expectations of business partners that engage in commercial transactions with foreign States. The restrictive approach is now widely reflected in case law, national statutes and international conventions, although it cannot yet be said to be universally recognised.

The commercial exception that forms the core of the restrictive approach generally applies both to immunity from jurisdiction (barring a State's courts from judging the actions of another State) and to immunity from execution (barring a State from taking coercive measures against another State's assets for the purpose of enforcing a judgement). But with regard to execution as opposed to jurisdiction, it applies somewhat differently and is generally more narrowly applied.

Although the restrictive approach is now widely recognised, State immunity continues to be an unsettled area of law. For example, the application of the commercial exception can vary from case to case. The key issue of whether the financial investment activities of a sovereign wealth fund are commercial or sovereign acts may thus be subject to considerable uncertainty; the only case located so far that squarely addresses the issue finds that they are sovereign acts and thus immune.

National laws also define the foreign State differently. Different jurisdictions use varying approaches both to foreign state-owned enterprises and to foreign central banks. Foreign state-controlled investors may have a significant ability to affect their degree of immunity through the structure used for their investments as well as through their choice of recipient jurisdiction.

The paper also examines more specifically the potential impact of foreign state immunity on host state regulation of foreign state controlled investment entities. In contrast to the extensive case law and vast literature devoted to foreign State immunity in the context of private lawsuits, little material is available on the issue of state immunity in the regulatory context. National and international efforts to codify the law of 
foreign state immunity in statutes or treaties, including the United Nations Convention on Jurisdictional Immunities of States, have generally skirted the issue of regulation. Regulators have rarely tested the law in court.

For criminal law, the clear trend toward the restrictive doctrine observed in the civil law field is not in evidence -- absolute immunity remains the general rule, though, in some cases, it may give way to other considerations (e.g. jus cogens norms). In the tax area, countries which all apply the restrictive theory to private law cases apply, in their domestic tax law, very different approaches to immunity from tax of foreign states. These range from broad exemptions from all direct taxes; exemptions limited to noncommercial activities (variously defined); and no exemptions. No general approach can be identified.

In the area of competition law, both EU and US regulators have taken the position that immunity is at least limited, but the law is not well-developed. In the EU, there may be some congruence between the scope of substantive competition law and immunity, i.e., in factual circumstances involving a sovereign act where an entity would thus be immune, competition law is also inapplicable. The European Commission has only taken enforcement action against entities owned by non-EU states in one case, dating back to the era of communist state trading companies. It rejected a claim of immunity by such companies although, despite serious violations, it applied only a declaratory remedy rather than a fine. Two subsequent cases have made clear the Commission's view that immunity should generally not interfere with the scope of EC competition law, but both its doctrinal approach to immunity and scope of remedial power remain unclear. The appeals to the European courts in these latter cases have been inconclusive.

In the United States, regulators have made clear in enforcement guidelines that they consider that most activities of foreign government-owned corporations operating in the commercial marketplace will be subject to U.S. antitrust laws to the same extent as the activities of foreign privately-owned firms. However, regulators have focused their limited enforcement resources elsewhere so the law with regard to public enforcement against foreign state entities remains largely undeveloped. Foreign state-owned enterprises have been successfully sued by private parties for violations of US antitrust law based on the commercial exception.

It is difficult to attempt to draw general conclusions about the impact of foreign state immunity on host state regulation. The issue is perhaps best analysed in functional terms on a sliding scale depending on a number of factors which would affect the strength of the case for applying a restrictive theory of immunity (or otherwise limiting immunity). Key factors include the nature of remedies to be applied (whether they are compensatory or punitive in nature), the public or private nature of the enforcement agency; and the applicable definition of the foreign state and type of foreign state entity at issue. Regulators may be able to achieve regulatory goals, at least in significant part, through careful attention to such issues in framing their regulatory actions. Increased international cooperation in seeking common approaches to similar regulatory issues, and publicising them, could also strengthen the legitimacy of regulatory action with regard to foreign state controlled investment entities by making it both more predictable and more uniform across different jurisdictions. 


\section{INTRODUCTION}

State-controlled investors - such as State-owned enterprises, sovereign wealth funds and public pension funds - have greatly expanded their foreign investments in recent years. Their range of investments has also grown to encompass a wider class of higher risk, higher yield assets, including equity, fixed income, real estate and alternative investments, including hedge funds and private equity.

Countries actively compete for these investments, because they recognise that they can bring important benefits for both home and host societies. For example, for recipient countries, such investment entities can tend to have long investment horizons and unique risk bearing capacities. For the home countries, they can help diversify economies, spread income across generations, and lower vulnerability to various types of risks (e.g. to adverse macroeconomic developments or shifts in commodity prices or exchange rates).

While investments by these entities offer many clear benefits, they also have been a source of concern for some in recipient countries. Some concerns relate to foreign state immunity. Under the doctrine of foreign state immunity, one State is not subject to the full range of rules applicable in the other State; the doctrine bars a national court from adjudicating or enforcing certain claims against foreign States. This paper examines two concerns relating to the doctrine of foreign state immunity: whether that doctrine, as applied to foreign State-controlled investors, may make it difficult for private parties to pursue legitimate claims against them and whether it creates regulatory enforcement gaps for host countries.

This note provides background for a discussion of investment policy issues raised by the doctrine of foreign state immunity in the context of consideration of the expanded role of foreign State-controlled investing entities as major investors in recipient markets. It follows up on earlier, more preliminary discussions in the October 2008 "Freedom of Investment" Roundtable based on a scoping paper ${ }^{1}$ reviewing this and other issues relating to foreign government controlled investors. A summary of the Roundtable discussion of foreign sovereign immunity states the following:

[Roundtable participants] hoped for greater predictability in this area, meaning that all market participants understand the legal status of foreign government-controlled investors (including the investor itself). At the present time, diversity of national laws and evolving jurisprudence make it hard for both foreign government investors and their business partners to predict the extent of foreign sovereign immunity. Several other Roundtable participants confirmed that this is an area relevant for international investment law that is not well-understood by policy makers nor by market participants.

The modern law and practice of state immunity has developed primarily to address litigation by private parties against foreign States. In contrast to the extensive case law and vast literature devoted to state immunity in the context of private lawsuits, little material is available on the issue of state immunity in the context of host state regulation. National and international efforts to codify the law of state immunity in statutes or treaties have generally skirted the issue of regulation. Regulators have rarely tested the law in

$1 \quad$ K. Gordon \& A. Tash, Government-controlled investors and recipient country investment policies: A scoping paper (OECD Jan. 2009). 
court. The paper thus seeks in particular to address the issue of the possible immunity of State-controlled investors from host-state regulation. Regulation frequently involves at least potential recourse to penalties such as fines (and not just compensation) and enforcement of the law by a public agency rather than a private party.

The analysis begins with a comparative overview of foreign state immunity. The general trend toward the acceptance of a restrictive theory - which provides for exceptions to immunity for transactions of a "commercial" nature - with regard to private law cases is noted, along with some continuing uncertainties. This section then addresses the rationale for state immunity, the issue of the definition of the foreign state, and the definition of commercial transactions. Some cases that have considered key issues such as the commercial or sovereign nature of sovereign wealth fund investment activities and the importance of the legal structure of the foreign investor are considered.

The third part of the note specifically addresses the immunity of foreign central banks which can play a variety of roles in State-controlled investment.

The note then turns to the principles applicable to state immunity in the field of regulation. The analysis begins with criminal law, where it is generally considered that absolute immunity continues to apply, but where there may be potential for evolution under certain conditions. State practice in two areas of regulation is then examined in more detail: the field of taxation, where national jurisdictions have long dealt with foreign states, but using very different approaches to immunity; and competition law, principally in the United States and European Union, which illustrates issues raised by the wide variety of procedures, remedies and sanctions used to achieve regulatory outcomes. A concluding section suggests some factors that may be helpful in evaluating issues of immunity with regard to a particular exercise of regulatory jurisdiction. Because cases in this area are relatively rare, an annex briefly examines a recent major case that may illustrate the application of some of these considerations in practice.

Before turning to the analysis, a few clarifications about the scope of this note may be appropriate. As a general rule, the choice of specific subject matter in relation to state immunity was decided on the basis of relevance for understanding the interaction of foreign government controlled investors with host country legal systems. First, given its focus on international investment, this note addresses foreign state immunity as it applies in national courts with respect to national law; foreign state immunity with regard to international crimes and related civil law damages actions arising out of such crimes are not addressed. Diplomatic and consular immunity and the personal immunity of heads of state are also not addressed. With regard to private parties, the analysis is largely limited to contract claims against foreign state entities. The principal focus is on the application of the law to legal persons and other entities rather than on individuals.

Second, the note is primarily descriptive of current law and practice. It does not at this stage seek to develop policy alternatives. For example, one policy approach could involve efforts to seek appropriate waivers of immunity from State-controlled investing entities; however, while waivers are an important issue, consideration of them has been postponed in favour of the prior question of seeking to identify what it would be necessary to waive.

Third, national legal systems have often developed other doctrines that may involve similar policy concerns to those at issue in state immunity. One prominent example is the discretionary doctrine of "act of state" in United States and United Kingdom law - which acknowledges that a state is sovereign within its own borders and excludes or limits review by national courts of the actions of other states in their own territory. Private litigants or regulators may find that foreign state defendants can successfully defend cases based on such doctrines in addition to or instead of state immunity. Except for certain passing references, 
however, this note is limited to state immunity and does not attempt to identify or address such possible parallel doctrines or defences.

Fourth, the paper does not focus on bilateral investment treaties (BITs) or investment arbitration because in that context, state-controlled investors would be primarily if not exclusively claimants rather than defendants. Some BITs expressly apply to investments by state-controlled investors while others do not expressly address the issue. However, the principal consequence of the inclusion of state-controlled investors in a BIT is to allow them to make claims against the host state under the treaty like other investors - it does not expose them to the potential liability or regulation which is the issue addressed here. 


\section{OVERVIEW OF STATE IMMUNITY}

The rules of state immunity address the extent to which a foreign state is protected from being sued in the courts of other countries. Immunity prevents a foreign state being made a party to proceedings in the forum state and/or will protect its property from being seized to satisfy a judgment. Immunity can extend to legal proceedings against the foreign state itself, its organs and enterprises, and its agents.

Immunity is generally considered to be a procedural bar. If it wishes, the defendant foreign state may waive its right to immunity and the case will then proceed. Such waivers can occur either in advance, such as in a contract, or after a dispute arises. ${ }^{2}$

International law determines the general rules of whether or not a foreign state should be accorded immunity by the courts of the forum (for foreign investment purposes, this is likely to be the courts of the host country). However, national law and national courts interpret and apply those rules and there are significant variations between countries.

The international community has tried for many years to agree a treaty on the subject. The first multilateral treaty to be concluded on the matter was the European Convention on State Immunity (ECSI), which came into force in 1976. However, only eight States (Austria, Belgium, Cyprus, Germany, Luxembourg, the Netherlands, Switzerland and the United Kingdom) are parties.

The negotiation of a broader treaty was extremely difficult. After decades of negotiations, agreement was finally achieved on the text of a treaty in 2004. The United Nations Convention on Jurisdictional Immunities of States (UNCSI) was adopted by the United Nations General Assembly and opened for signature in December 2004. The UNCSI provides that it will enter into force once thirty States have submitted their ratification, acceptance, approval or accession with the Secretary-General of the United Nations. Twenty-eight States signed the treaty during the period open for signature (which is now closed). As of March 2010, eight States (Austria, Iran, Kazakhstan, Lebanon, Norway, Portugal, Romania and Sweden) had ratified or acceded to the Convention. ${ }^{3}$ The UNCSI adopts a restrictive approach to state immunity, but the degree to which the restrictive approach is recognised by States today remains a subject of some debate.

\section{International acceptance of a restrictive approach to foreign state immunity}

International law imposes a general requirement that foreign states should not be subject to suit or to execution. But there are important exceptions to this rule, exceptions that have been growing over the

2 Immunity applies to the foreign state being made a defendant in a suit. Where foreign state entities are plaintiffs or claimants, they are generally treated like other litigants. Thus, a foreign state investor in a mutual fund would see its claims against the fund treated like those of other claimants. Moreover, where a foreign state brings suit, it generally acts as a waiver of its immunity with regard to related counterclaims.

Some multilateral treaties dealing primarily with other subjects contain provisions on immunity in specific areas such as state-operated merchant shipping. See, e.g., UN Convention on the Law of the Sea, arts 35$36,95-96$. 
years. At one time, States had absolute immunity. Proceedings against foreign states were inadmissible without their consent.

As States became involved in commercial activities, however, some national courts began to apply a more restrictive law of immunity by reference to the type of activity carried out by the State. Under the restrictive law of immunity, courts recognize immunity for acts carried out by a State in the exercise of its sovereign authority but will deny immunity for acts of a commercial or private law nature.

The movement was begun in civil law jurisdictions such as Italy, Belgium and Egypt starting in the nineteenth century, and gradually spread elsewhere; the 1963 decision of the German Constitutional Court in the Empire of Iran case, which applied the restrictive approach after a thorough review of international law and state practice, was influential. ${ }^{4}$

In common law jurisdictions, a key development was the 1952 Tate Letter from the US Department of State, which reviewed international practice and the policy issues, and announced that the Department would henceforth follow the restrictive theory. ${ }^{5}$ Subsequently, in 1976, the United States adopted the Foreign Sovereign Immunities Act (US FSIA). This was the first national statute governing sovereign immunity; it codified a restrictive approach and provided that the courts would henceforth be charged with the determination of immunity issues under the FSIA. Other common law States, including the UK, Canada, Australia, Malaysia, Pakistan, South Africa and Singapore soon also enacted legislation incorporating the restrictive approach. ${ }^{6}$ Argentina is the only civil law jurisdiction that has enacted general legislation on state immunity; the legislation adopts a restrictive approach. ${ }^{7}$

It has long been the custom to refer to a "trend" toward an increasing number of States adopting restrictive immunity. That notion both recognises movement towards general adoption of the restrictive theory and the existence of residual resistance. Reviews of state practice prior to adoption of the UNCSI generally concluded that the restrictive doctrine is widely though not universally recognised. For example, a major Council of Europe project to review state practice on state immunity involved the collection of materials from 28 member or observer States of the Council of Europe. The survey demonstrates a fairly consistent preference for the application of a restrictive rule. ${ }^{8}$ A continued application of the absolute rule relating to commercial acts, however, appeared in court decisions in Bulgaria, the Czech Republic, Poland, Romania and Russia. Overall, the conclusion was that the theory of absolute immunity continues to play a role, albeit a marginal one, in the practice of European States. ${ }^{9}$

$4 \quad$ Empire of Iran, German Federal Constitutional Court, 45 ILR 57 (1963). For the historical development of the restrictive approach, see the Commentary prepared by the International Law Commission on its 1991 Draft Articles on Jurisdictional Immunities of States and their Property (hereinafter, the "ILC Commentary"), $\S \S 14$ et seq., available at http://untreaty.un.org/ilc/texts/instruments/english/commentaries/4_1_1991.pdf .

Letter of Jack B. Tate, Acting Legal Adviser of the Department of State, to Acting Attorney General (19 May 1952), reprinted in Alfred Dunhill of London v. Republic of Cuba, 425 U.S. 682, 711 (1976).

The State Immunity Act 1978 (UK SIA); State Immunity Act (1982) (Canada SIA); Foreign State Immunities Act 1985 (Australia FSIA); Immunities and Privileges Act 1984 (Malaysia); State Immunity Ordinance 1981 (Pakistan); State Immunity Act 1979 (Singapore); Foreign State Immunities Act 1981 (South Africa).

Law No. 24,488 of 31 May 1995.

Hazel Fox, The Law of State Immunity, (2d ed. 2008) (hereinafter Fox) at p. 232.

The situation in Russia is uncertain. Article 127 of the Civil Code of Procedure adopted in 1994 made provision for reform of the absolute rule of state immunity, but as of March 2009 no such law had been 
The state practice of many States is scanty and difficult to interpret. Even in the context of the Council of Europe project, many of the country submissions are difficult to evaluate precisely. This leaves considerable room for interpretation of state practice. For example, a recent monograph argues that a broad range of countries continues to hold to the doctrine of absolute immunity. ${ }^{10}$

However, since the last major review of state practice, agreement was reached on the text of UNCSI, which sets forth a restrictive doctrine. A very wide range of countries spoke in support of the adoption of the draft Convention during its consideration by the Sixth Committee of the UN General Assembly in 2004. These included a number of countries, such as China, India and Iran that have previously been associated with the absolute doctrine. ${ }^{11}$

The full impact of the Convention remains to be seen. The Convention was a significant factor in the 2006 decision of the Japanese Supreme Court to overturn the long-standing absolute approach in Japan and adopt the restrictive theory. ${ }^{12}$ Japan signed UNCSI in January 2007 shortly after the decision was rendered. The UNCSI has been cited in a number of other cases, as a recent expression of international consensus. ${ }^{13}$

At the same time, uncertainty remains, as exemplified by the position taken by China in a recent case. The case involved an attempt by a private creditor to register an arbitral award in Hong Kong and execute against property of the Democratic Republic of Congo (DRC). ${ }^{14}$ The property in question was amounts owing to the DRC by Chinese State-owned companies as "Entry Fees" under contracts for, inter alia, the right to exploit the DRC's mineral resources.

The Hong Kong Secretary for Justice intervened on the issue of state immunity to argue for absolute immunity and submitted a letter from the Chinese Ministry of Foreign Affairs Office in Hong Kong. The letter states that China has always taken the stance that sovereign states enjoy absolute immunity before foreign courts:

The consistent and principled position of China is that a state and its property shall, in foreign courts, enjoy absolute immunity, including absolute immunity from jurisdiction

enacted. See national contribution of Russia to Council of Europe database on State practice on State immunity dated March 2009, available at

http://www.coe.int/t/e/legal\%5Faffairs/legal\%5Fco\%2Doperation/public\%5Finternational\%5Flaw/state\%5 Fimmunities/.

See Ernest K. Bankas, The State Immunity Controversy in International Law: Private Suits Against Sovereign States in Domestic Courts (2005).

China spoke in favour of the adoption of the draft convention in the Sixth Committee in 2004 and signed UNCSI in September 2005. Iran similarly supported adoption of the Convention and ratified it in September 2008. Russia signed the Convention in December 2006. See Fox at p. 169, 235.

Case No. 1231 [2003], 1416 Saibansho Jiho 8 (Sup. Ct. 21 July 2006). See case note in English by C. Jones, 100 AJIL 908 (Oct. 2006).

See, e.g., Jones v. Ministry of Interior of Saudi Arabia, [2006] UKHL 26 (Lord Bingham) ("Despite its embryonic status, this Convention is the most authoritative statement available on the current international understanding of the limits of state immunity in civil cases ...".); (Lord Hoffmann) ("It is the result of many years work by the International Law Commission and codifies the law of state immunity").

FG Hemisphere Associates LLC v. Democratic Republic of the Congo, High Court of the Hong Kong SAR (12 December 2008), available at http://legalref.judiciary.gov.hk/lrs/common/search/search_result_detail_body.jsp?ID=\&DIS=63653\&QS=( firm)\&TP=JU 
and from execution, and [it] has never applied the so-called principle or theory of 'restrictive immunity'.

The letter does not refer to China's signature of UNCSI and the judge was "at a loss on how the stance stated in the letter is to be reconciled (if at all) with the signing of the Convention". ${ }^{16}$

Universal acceptance of restrictive immunity thus does not exist at present. For most situations, the foreign state's views on absolute as opposed to restrictive immunity are not of great practical importance because state immunity is governed by the law of the forum. Where it is well-established in the forum state that restrictive immunity applies, the particular foreign state's views on immunity will not affect the court's approach. The foreign state's views on immunity could be an important factor, however, in the overall political climate of a case as well as in determining the scope of cooperation with regard to the gathering of evidence.

\section{Rationale for State immunity law}

State immunity has been justified on a variety of grounds. One ground is the status of equality attaching to the independent sovereign, which is said to preclude one State from exercising jurisdiction over another under the principle of par in parem non habet jurisdictionem: one sovereign State is not subject to the jurisdiction of another State. This was often invoked as the basis for absolute immunity, as for example in the frequently-cited 1849 French case, Lambège et Pujol:

L'indépendance réciproque des Etats est l'un des principes les plus universellement reconnu du droit des gens ... De ce principe, il résulte qu'un gouvernement ne peut être soumis, pour les engagements qu'il contracte, à la juridiction d'un Etat étranger. ${ }^{17}$

Although this rationale is primarily associated with the absolute theory, it has also been framed in some cases in a manner consistent with the restrictive approach to sovereign immunity, by limiting its effective scope to the sovereign acts of the foreign State:

It is necessary to start from first principle. This basis on which one State is considered to be immune from the territorial jurisdiction of the courts of another State is "par in parem non habet imperium", which effectively means that the sovereign or governmental acts of one State are not matters on which the courts of other States will adjudicate. ${ }^{18}$

A second ground is that of non-intervention in the internal affairs of other States. As noted by Brownlie, "the rationale rests equally on the dignity of the foreign nation, its organs and representatives,

15

The letter was from the Office of the Commissioner of the Ministry of Foreign Affairs (MFA) of the People's Republic of China (PRC) in Hong Kong to the Constitutional and Mainland Affairs Bureau of the Hong Kong Government.

See FG Hemisphere $\S 81$. Under Article 18 of the 1969 Vienna Convention on Treaties (to which China is a party), a State that has signed a treaty is obliged to refrain from acts which would defeat the object and purpose of the treaty. The Secretary recognised that the Hong Kong court was not bound by the letter. The court did not find it necessary to resolve the issue of whether Hong Kong law currently recognises restrictive immunity because it found the assets in question not to be in commercial use and thus immune under either theory. The case is reportedly on appeal.

French Cour de cassation, Sirey 1849, I, 81.

I Congreso del Partido, [1983] 1 AC 244, 64 ILR 307; see also P. Mayer \& V. Heuzé, Droit international privé (9th ed. 2007) § 324. 
and on the functional need to leave them unencumbered in the pursuit of their mission". ${ }^{19}$ There is also no doubt that court proceedings against foreign states may generate tensions and interfere with the conduct of international relations.

A number of commentators have pointed to another aspect that may be relevant in the current context with regard to SWFs. It is that the economic interests of States may affect their interpretation of state immunity principles. An eminent professor offered a version of this thesis in his conclusions to a 2004 international conference on state immunity: «les considérations propres aux Etats interfèrent largement avec l'interprétation prétendue du droit international dans l'élaboration de leur propre droit national des immunités. [...] Ce sont largement les intérêts des Etats et de leurs entreprises qui commandent les réglementations nationales des immunités des Etats étrangers. ${ }^{20}{ }^{20}$

In this regard, in the current context in which States are recipients of investment by SWFs and have been actively seeking to attract SWF capital to their domestic business sectors, it is important to note that the international law of state immunity generally requires that States provide each other with certain protections from national court proceedings. It does not preclude States from offering additional immunities. In other words, the law creates a floor of minimum protection, but does not create a ceiling. As a matter of the law of state immunity, States are free to adopt laws, treaties or policies that extend immunities, as a matter of discretion, beyond those required by international law. ${ }^{21}$ For example, bilateral tax treaties may grant immunity to specified entities that go beyond those required under international law. In the current context, competitive pressures may express themselves through broader discretionary grants of immunity to important potential investors such as SWFs.

A variety of factors may come into play in this area. The uncertainty about the boundaries of state immunity frequently makes it difficult to determine whether a particular extension of immunity is mandated by international law, is discretionary or is in a middle ground where it reflects the State's view of what is mandatory under international law in an uncertain area. Where the law is uncertain, there can be good reasons to clarify the applicable policy beforehand. In some cases, however, it is possible that framing a policy as one related to state immunity, without clarifying whether it is a discretionary grant or a mandatory one, may unduly limit debate on the merits of the policy as such.

\section{The definition of the State and the importance of the legal structure of the foreign entity}

As noted in the Santiago Principles developed by the International Working Group of Sovereign Wealth Funds, SWFs can take a variety of forms: separate legal entities (e.g., Qatar, UAE (ADIA), Australia, and Singapore's Temasek and GIC) or pools of assets without separate legal personality (e.g., Chile, Canada (Alberta), Mexico, Norway, Russia, Timor-Leste, and Trinidad and Tobago). ${ }^{22}$ For the latter

19 I. Brownlie, Principles of Public International Law (7th ed. 2008) p. 326.

["Considerations specific to States significantly influence the supposed interpretation of international law in the development of their own national law of immunity. [...] To a substantial degree it is the interests of States and businesses in those States that determine the national rules applicable to the immunity of foreign States".] Paul Lagarde, Conclusions générales, in I. Pingel, ed., Droit des immunités et exigences du procès équitable, (2004), p. 152 (citing note by L. Collins on the UK SIA in Revue critique de droit international privé, p. 171 (1980)).

There have been a number of attempts to find other legal grounds to limit immunity. One notable example is the argument that excessive immunity denies the right of private parties to access to justice protected by, for example, Article 6 of the European Convention on Human Rights. See generally I. Pingel, ed., Droit des immunités et exigences du procès équitable (2004).

See International Working Group of Sovereign Wealth Funds, Sovereign Wealth Funds; Generally Accepted Principles and Practices (Santiago Principles) (October 2008) at p. 15, available at 
type, the owner may exercise the functions of the governing body(ies) through one or more of its organizational units (e.g., a ministry, a parliamentary committee, etc.). In some cases, operational management may be delegated to an independent entity, such as the central bank (e.g., Chile, Norway, Timor- Leste, and Trinidad and Tobago) or a separate statutory agency (e.g., Canada (Alberta)).

As a preliminary matter, it should be noted that the restrictive theory of sovereign immunity focuses primarily on the nature of the transaction at issue, not on the status or structure of the foreign entity. An entity carrying out a sovereign act is immune regardless of its public or private status; even a State is not immune if the transaction is commercial. Given this general approach, the modern focus is rather on whether the transaction at issue is a sovereign or commercial act rather than focusing on the structural relationship between the foreign entity and the foreign state. ${ }^{23}$

For a number of reasons, however, structure is likely still of great importance with regard to SWFs. ${ }^{24}$ First, while the inquiry may have shifted to primarily to one about the nature of the transaction, in close cases the structural and operational independence of the entity from the State may be an important factor in characterising the act as sovereign or commercial. Second, while structure may now be of secondary importance with regard to immunity from adjudication in civil cases, it can re-emerge as a critical issue with regard to immunity from execution. Third, some structures used in SWFs, and in particular foreign central banks, increasingly benefit from even stronger protection than the foreign State. Fourth, structure can be of critical importance in areas where absolute immunity may still apply, as may be the case with regard to criminal law and aspects of regulation. Where entities that comprise the State benefit from absolute immunity, the issue of the definition of the contours of the State becomes of critical importance.

Some general observations can be made with regard to two important types of structures: a separate State-owned legal entity such as a State-owned enterprise (SOE); and a structure that is part of the State without separate legal personality. (The special rules applicable to foreign central banks are addressed below after the section on immunity from execution because it is in that area that they benefit from special protection.)

In broad terms, two principal approaches are taken to the relationship between SOEs and the foreign State. ${ }^{25}$ Under the ECSI and in the UK, Australia and most civil law States, such companies are placed outside the State providing they operate independently from the State. The ECSI uses separate legal personality and the capacity to sue and be sued as the factors to determine whether an entity or company operates independently of the State. ${ }^{26}$ In general, separate entities are not entitled to immunity from

http://www.iwg-swf.org/pubs/eng/santiagoprinciples.pdf. The Principles further divide separate legal entities into separate legal "identities" (legal entities under public law with full capacity to act and governed by a specific constitutive law) and state-owned corporations. See id. p. 11.

The Santiago Principles refer only obliquely to the issue of state immunity. Principle 15 states that "SWF operations and activities in host states should be conducted in compliance with all applicable regulatory and disclosure requirements of the countries in which they operate". However, it appears clear that this general statement is not intended to affect the issue of state immunity. The Principles elsewhere note that "recipient countries may grant to SWFs certain privileges based on their government status, such as sovereign immunity and sovereign tax treatment". See Santiago Principles at p. 19 \& p. 22 n. 35.

See Fox at p. 436.

Id.

Such enterprises are addressed under national laws and treaties under various rubrics, including "separate entities" (UK, Australia), "agencies and instrumentalities" (US) and "legal entities" (ECSI).

The ECSI (art. 27) distinguishes agencies of the State from its organs by excluding from the expression "Contracting State" any legal entity of a Contracting State which is distinct therefrom and is capable or 
adjudication or execution. Such entities are immune only if they carry out acts in the exercise of sovereign authority. In contrast to the ECSI-type approach, the US FSIA defines the overall foreign State more broadly. It includes certain majority State-owned companies under its definition of "agencies and instrumentalities" of the foreign State. ${ }^{27}$

The Sarrió proceedings against the Kuwait Investment Office and Kuwait Investment Authority. The cases brought by Sarrió, a Spanish company, against the Kuwait Investment Office (KIO) and Kuwait Investment Authority (KIA) illustrate some aspects of the ECSI-type approach in a context involving an SWF. In Switzerland, Sarrió obtained pre-judgment attachments of bank accounts of KIA/KIO in Geneva and Zurich to secure payment of a contract-type claim then-pending in the Spanish courts. ${ }^{28}$ KIA was described in contemporaneous English proceedings also brought by Sarrió against KIA as the investment arm of the government of Kuwait, though with a separate legal identity from the government and State. Its head office was in Kuwait and it was domiciled there. It had a long-established branch office in London where it was known as $\mathrm{KIO}^{29}$

The dispute leading to the attachment related to the sale of part of Sarriós paper products business to Grupo Torras, a Spanish holding company $96 \%$ owned by KIA/KIO. After a Grupo Torras affiliate allegedly failed to comply with the payment terms, Sarrió filed a civil lawsuit in Spain in February 1993 naming KIA/KIO, Grupo Torras and certain subsidiaries as defendants. ${ }^{30}$ Grupo Torras had entered into a "suspensión de pagos" (a form of insolvency procedure) and Sarrió sought to impose liability for the alleged contract breach on KIA/KIO in its capacity as the dominant shareholder of Grupo Torras. ${ }^{31}$

In May 1993, shortly after it commenced the Spanish proceeding, Sarrió attached KIA/KIO accounts at banks in Geneva and Zurich to secure the payment of the claim in Spain. On appeal by Kuwait, the Swiss Federal Tribunal rejected Kuwait's claim of immunity. ${ }^{32}$ Kuwait conceded that the underlying Spanish contract giving rise to Sarrió's claim involved private rather than sovereign acts. It argued that the attached assets were immune because they were part of the Future Generations fund. This fund, created in 1976 by a decree of the Emir of Kuwait, was designed to provide for the future needs of the Kuwaiti people once the country's oil reserves are exhausted. It was managed by KIA/KIO.

suing and being sued. Such distinct entities are not part of the State even if they have been entrusted with public functions. Under Article 27(2), proceedings may be brought against such entities "in the same manner as a private person" except in respect of sovereign acts.

The US uses its broader definition of the State for purposes of determining when to plead immunity for a US agency in a foreign court. As noted above, the decision on immunity rests with the foreign court.

Kuwait v. X, Swiss Federal Tribunal (24 January 1994). The case is unreported, but is partially reproduced at [1995] Rev. Suisse D. int. eur., Vol. 5, at p. 593.

Because KIO was merely a branch of KIA, the two were treated as a single entity. For convenience, this convention is used in this note and they are generally referred to as KIA/KIO.

Information has not yet been obtained about whether state immunity was raised as a plea in the Spanish proceedings brought by Sarrió or their outcome. In August 1996, a decision of the English Court of Appeal in the related case brought by Sarrió against KIA/KIO noted that the jurisdiction of the Spanish court over $\mathrm{KIA} / \mathrm{KIO}$ had been established by then, though only after a number of interlocutory rulings.

The events surrounding the Grupo Torras insolvency spawned other lengthy litigation in multiple jurisdictions, including numerous cases in Spain and a suit by Grupo Torras against its former managers that gave rise to one of the longest fraud cases in UK history.

Under Spanish law, a dominant shareholder of an insolvent company can be made liable for that company's debts under certain circumstances.

Kuwait v. X, Swiss Federal Tribunal (24 January 1994). 
The appeal was brought by Kuwait, not by KIA/KIO. The court noted that KIA/KIO might not have the power to invoke immunity on its own behalf under Swiss case law consistent with the approach to SOEs in the ECSI. The court found it unnecessary to decide the issue because only Kuwait had appealed.

The issue of whether KIA/KIO was part of the State was not relevant to immunity from jurisdiction because the conceded private law nature of the acts excluded immunity in any event. But it was relevant to immunity from execution: the accounts were in the name of KIA/KIO and the court found that Kuwait would only have standing to claim immunity for the accounts if KIA/KIO were part of the State. The court found that KIA/KIO were independent entities from the State and that Kuwait was not the proper party to invoke immunity for them.

In rejecting Kuwait's argument that KIA/KIO formed part from the State, the court noted that the 1982 law creating KIA provided that KIA had an autonomous status and that Kuwait had recognised that it was an independent public authority. In addition, the court relied on various documents including KIA's articles (statuts), statements by KIA that it was independent, and letters from KIA and its representatives to government authorities and private parties. The court also underlined that KIA had brought suit in its own name in various proceedings in England and Spain. In the face of this evidence, the court was not persuaded by a contrary legal opinion provided by the Kuwaiti government. The government's economic dominance over KIA, including Kuwaiti ministers sitting on its council board, and that the fact that KIA's investments were made to benefit the State were found to be of no relevance. ${ }^{33}$

As noted above, Sarrió commenced parallel proceedings against KIA/KIO in Spain and in the UK. In the English proceeding, KIA/KIO initially claimed it was part of the Kuwaiti State within the meaning of the UK SIA, but subsequently withdrew that argument. (It continued to claim to be a "department of government of the State of Kuwait", a claim which may have been important with regard to state immunity from tax under UK law - see below in the section on tax) It did not claim immunity. ${ }^{34}$ Sarrió's English action was ultimately dismissed by the House of Lords in 1997 on the ground that the earlier-filed action in Spain covered similar issues.

As noted, the US FSIA applies a broader approach than the ECSI to defining the overall foreign State. Generally, a State-owned company will be an agency or instrumentality under the US FSIA if it has separate legal personality, the foreign State directly holds a majority interest, and the company is incorporated in the foreign State. ${ }^{35}$ Where the State-owned company is engaged in commercial activities immunity is removed when FSIA requirements are met and it is treated in many respects like a private party, as in other jurisdictions. However, due to the status of the company as an agency and instrumentality of the State, the US FSIA provides for some important privileges to be retained by it even when it is not immune. For example, pre-judgment attachment of property is excluded unless immunity from such attachment has been specifically waived. ${ }^{36}$

After denying the claim to immunity on the basis that Kuwait was not the proper party to make it, the court suggested that a claim of immunity would have been denied in any event. The court's wording appears carefully chosen to leave open the question of whether it would be sufficient for the account to be linked to the future generation fund for it to be immune from execution. The court's principal finding was that the evidence was insufficient to establish that the attached assets were dedicated to the public service of the State. The court then went on to say that "moreover" [par ailleurs], the evidence did not sufficiently link the account to the future generation fund. The court appeared to carefully avoid stating that the general finding was made because of the lack of evidence linking the fund to the account. 
Although agencies and instrumentalities are part of the broader State under the US FSIA, they are not subject to all of the same rules as the State itself. Different rules apply to provide more protection to a State than to its agencies and instrumentalities on issues such as service of process, execution and punitive damages. ${ }^{37}$

The 2003 decision of the US Supreme Court in Dole has clarified the number of State-owned companies considered to be agencies and instrumentalities of the foreign State under US law. ${ }^{38}$ The Supreme Court found in Dole that the requirement, for an entity to be an agency or instrumentality, that a "majority of [the] shares [be] owned by a foreign state" was satisfied neither by indirectly-held companies nor by companies privatised as of the date of the complaint. Companies held by the State indirectly or that have been privatised as of the date of the complaint are now more likely to be treated like private companies. $^{39}$

In general, it appears that for an independent SOE with the power to sue and be sued, immunity from jurisdiction in civil cases would likely depend primarily on whether its investment activities at issue are considered to be commercial or sovereign acts. If they are considered to be commercial, the SOE would generally be treated similarly to a private company in most jurisdictions that apply the restrictive theory. In the US, it would be treated largely like a private company and would not be immune, but, if directly owned by the State, would benefit from certain additional protections. If the activities at issue are considered to be sovereign acts, the enterprise would generally benefit from immunity from adjudication in all jurisdictions unless immunity is waived.

A structure established as a pool of assets, part of the State without separate legal personality, would likely generally be considered to form part of the foreign State. As for foreign States generally, for immunity from jurisdiction, the most important criterion would remain the commercial or sovereign nature of the investment acts in question.

While the key distinction between commercial and sovereign acts is now well-established in most countries, its application in specific cases is frequently still uncertain.

\section{The commercial exception}

A commercial or private law exception to immunity is the hallmark of the restrictive approach. When a State is engaged in a commercial transaction, it acts as a trader, not as an independent sovereign state. Because it has ceased to act in a public capacity, it has no immunity for the commercial transactions. The distinction between the two types of acts is frequently addressed, especially in civil law jurisdictions, using the Latin terms, acts jure imperii and acts jure gestionis.

Immunity from jurisdiction is distinct from immunity from execution. Immunity from execution comprises measures of constraint directed against property of the foreign state either for the purpose of

Compare US FSIA §§ 1608(a) \& (b) (service of process); §§ 1610(a) \& (b) (execution); see also § 1606 (punitive damages).

Dole Food Co. v. Patrickson, 538 US 468 (2003).

In the absence of direct majority ownership, a company can still be an agency or instrumentality if it is "an organ of a foreign state or a political subdivision thereof". US FSIA § 1603(b)(2). The Supreme Court granted certiorari (leave to appeal) in 2007 on whether a Canadian power company indirectly-held by a province was an "organ," see Powerex Corp. v. Reliant Energy Servs.,127 S.Ct. 1144 (2007), but the majority decision dismissed the case on jurisdictional grounds. Powerex Corp. v. Reliant Energy Servs.,127 S.Ct. 2411 (2007). 
enforcing judgments or for the purpose of pre-judgment attachment. Both types of immunity are subject to a commercial exception, but it is generally more narrowly applied with regard to execution.

\section{a. Immunity from jurisdiction}

The most frequent basis for the exclusion of immunity for a transaction are its private law character or its commercial nature. The first is used in many civil law countries while the second is used in most of the national legislation adopted in common law countries, but both tend to the same result. For convenience, this note refers generally to the commercial exception to encompass both the commercial and private law exception.

UNCSI Art. 2(c) defines "commercial transactions" to cover a wide range of contracts and transactions:

(i) any commercial contract or transaction for the sale of goods or supply of services;

(ii) any contract for a loan or other transaction of a financial nature, including any obligation of guarantee or of indemnity in respect of any such loan or transaction;

(iii) any other contract or transaction of a commercial, industrial or trading or professional nature, but not including a contract of employment of persons.

One of the key issues in identifying a commercial transaction relates to whether the nature or purpose of the transaction is determinative. The well-known Empire of Iran case explained the concerns about the expansion of immunity that results from reliance on the purpose of the transaction: "[T]he distinction between sovereign and non-sovereign cannot be drawn according to the purpose of the State transaction and whether it stands in a recognisable relations to the sovereign duties of the State. For, ultimately, activities of the State, if not wholly, then to the widest degree, serve sovereign purposes and duties ...."40

A number of OECD jurisdictions focus on the nature of the act and in some cases this approach is mandated by statute. ${ }^{41}$ Courts in some other countries continue to refer to the purpose of the acts in making determinations about immunity. The UK SIA does not expressly address the issue and UK law arguably occupies a middle ground. In the I Congreso del Partido case, Lord Wilberforce broadened the test to some degree into a consideration of the "whole context" of the transaction that can involve elements of both tests. ${ }^{42}$ French cases have considered both the nature and the purpose of the acts at issue in making the determination; in order to grant immunity, they have required that the act either be an "acte de puissance publique" or that it have been carried out "dans l'intérêt d'un service public". ${ }^{43}$

The UNCSI provision in this area reflects the predominant focus on the nature of the act but also the continuing lack of general agreement to exclude entirely consideration of purpose. Article 2.2 UNCSI

\footnotetext{
$40 \quad$ See Empire of Iran case, German Federal Constitutional Court (30 April 1963), 45 ILR 57.

$41 \quad$ See Empire of Iran ("As a means for determining the distinction between acts jure imperii and jure gestionis one should rather refer to the nature of the State transaction or the resulting legal relationships; and not the motive or purpose of the State activity."); US FSIA $\S 1603(d)$; Canadian SIA $\S 2$.

42 I Congreso del Partido, UK House of Lords, [1983] 1 AC 244, 64 ILR 307.

$43 \quad$ P. Mayer and V. Heuzé, Droit international privé (9th ed. 2007) § 325.
} 
provides for primary consideration of the nature of the act, but notably allows consideration of the purpose if that is the practice in the State of the forum. ${ }^{44}$

Because of the difficulty of applying general tests, many countries that have statutes accompany the general criteria with lists of transactions for which immunity is excluded. This approach is also used in the UNCSI, which, in addition to the transactions defined in Art. 2 as quoted above, contains a series of specific exceptions in Articles 11 (employment contracts), 14 (intellectual property), 15 (companies), 16 (shipping) and 17 (arbitration agreements). These provisions can greatly assist in defining the scope of immunity.

Another key question in the application of the commercial exception is the identification of the relevant act for consideration. Acts at the beginning of a transaction may be of one nature, but courts may find that the relevant acts for immunity purposes are later acts of a different nature. For example, an Italian Court of Cassation decision found that, while a bond issue by the government of Argentina was a private commercial matter not benefiting from immunity, the subsequent default on Argentina's public debt obligations, being motivated by the sovereign purpose of managing a serious economic crisis, did confer immunity from jurisdiction. ${ }^{45}$ In contrast, German cases have applied a presumption that once a State has entered a market a characterization of that act as commercial continues, regardless of the nature of the act constituting its subsequent breach. ${ }^{46}$

\section{b. Immunity from execution and the commercial exception}

Execution against State property generally raises more difficulties than adjudication. As noted by one author, to judge a foreign state is one thing, to subject it to coercive measures of execution is another. ${ }^{47}$ At the same time, strong considerations of principle militate in favour of aligning jurisdiction and execution so that where a national legal system has jurisdiction to render a judgment, it can also enforce that judgment.

Different countries have adopted different approaches, but most limit execution against foreign States more than adjudication. In particular, immunity from execution must generally be specifically waived as such; a waiver of immunity from jurisdiction does not affect immunity from execution.

A number of civil law jurisdictions have adopted the principle that a State enjoys immunity from execution for property in use for sovereign purposes, but not for property in use for commercial purposes. This approach was adopted in the German Constitutional Court's 1977 decision in the Philippine Embassy

44

Article 2.2 UNCSI: "In determining whether a contract or transactions is a commercial transaction under paragraph 1(c), reference should be made primarily to the nature of the contract or transaction, but its purpose should also be taken into account if the parties to the contract or transaction have so agreed, or if, in the practice of the State of the Forum, that purpose is relevant to determining the non-commercial character of the contract or transaction".

See Borri Loca v. Republic of Argentina, Cassazione civile (sez. un.), decision no. 11225 of 27 May 2005.

46

Fox at p. 517.

D. Carreau, Droit international public $\left(9^{\text {th }}\right.$ ed. 2007). 
case, and in subsequent cases in Italy and Spain. ${ }^{48}$ The Australian, Canadian and UK statutes generally allow for execution against foreign state property in use or intended for use in commercial purposes. ${ }^{49}$

French and US law also distinguish between property used for sovereign as opposed to private purposes. However, for execution against State property, they generally require a link between the property and the original claim. ${ }^{50}$ Both France and the US eliminate this special requirement of a link between the property and the underlying claim in cases involving property of an SOE rather than the foreign State itself. Thus, in Sonatrach, the Cour de Cassation expressly distinguished between foreign State and State agencies, finding that "the assets of public entities, distinct from the foreign State, whether or not enjoying legal personality, which are part of a group of assets (patrimoine) which been dedicated to activities in the private law sector, may be seized by all creditors of the public entity". ${ }^{51}$

Immunity of execution was the most difficult problem encountered during the lengthy process leading to UNCSI. In 2002, agreement was achieved on a restrictive theory for post-judgment execution. However, there was still uncertainty about whether the assets would be required to have a link with the claim. Ultimately, the requirement of a link with the claim was eliminated. Article 19 thus allows postjudgment execution against property used for commercial purposes located in the territory of the forum. The property must have "a connection with the entity against which the proceedings was directed". However, the Convention deals separately with pre-judgement and post-judgment execution, and Art. 18 strictly limits pre-judgment attachment.

AIG v. Republic of Kazakhstan. In a recent English case, the court appeared to consider that an SWF that invests in securities is engaged in immune sovereign activity by virtue of its general purpose of accumulating assets in the public interest; the invested assets were accordingly immune from execution. ${ }^{52}$ The case arose after an AIG affiliate had obtained an ICSID arbitration award against the Republic of Kazakhstan and registered it as a judgment in England. AIG then sought to execute against cash and securities located in a London bank. The National Bank of Kazakhstan (the central bank) intervened in the case and claimed that the assets were immune from enforcement under the UK SIA.

48

The Philippine Embassy case, 65 ILR 146 (1977); Condor and Filvem v. Minister of Justice, Italian Constitutional Court, 101 ILR 394 (1992); Abbott v. South Africa, Spanish Constitutional Court, 113 ILR 411 (1992).

See Australia FSIA $§ 32(1)$ (immunity generally excluded for commercial property); Canadian SIA $\S 11$ (execution against foreign State property allowed where the property is used or is intended for commercial activity); UK SIA $\S 13(4)$ (property in use or intended for use in commercial purposes is subject to attachment).

See US FSIA $\S 1610(\mathrm{a})(2)$; see République démocratique du Congo, French Cour de Cassation, (1ere ch. Civ. 25 January 2005) (immunity can only be excluded "lorsque le bien saisi se rattache ... à une opération économique, commerciale ou civile relevant du droit privé qui donne lieu à la demande en justice ») ; Eurodif, French Cour de cassation, (1 ${ }^{\text {re }}$ Ch. 14 March 1984), JCP II, 2205, note Synvet.

Société Sonatrach v. Migeon, French Court of Cassation (1 October 1985), 77 ILR 525 [“Les biens des organismes publics, personnalises ou non, distincts de l'Etat étranger, lorsqu'ils font partie d'un patrimoine que celui-ci a affecte a une activité principale relevant du droit prive, peuvent être saisis par tous les créanciers, quels qu'ils soient, de cet organisme".]; see US FSIA § 1610(b)(2).

AIG Capital Partners Inc. and Another v. Kazakhstan, [2005] EWHC 2239 (Comm.), 129 ILR 589. In addition to its finding with regard to the non-commercial nature of the investments discussed here, the court also based its decision on the second alternative ground that the National Fund assets benefited from absolute immunity because they constituted "property" of the Kazakhstan central bank. This aspect of the case is discussed below in the section on central banks. 
The assets were cash and securities that formed part of the National Fund of Kazakhstan (the "National Fund"), a sovereign wealth fund created in 2000 by a presidential decree. Kazakhstan conceded that, but for state immunity, the National Fund had an attachable interest in the accounts.

Under an agreement of "trust management" between the Republic of Kazakhstan and the central bank, the National Fund was managed by the central bank. The central bank was given the right to invest the National Fund assets. The fee arrangement between the government of Kazakhstan and the central bank provided for the central bank earning a commission if the Fund profited, but paying compensation to Kazakhstan if the Fund incurred losses. The Government was identified as the beneficiary under the agreement.

Under the terms of a global custody agreement (GCA) between the central bank and the London bank, the London bank agreed to hold, in the name of the central bank, cash and securities of the National Fund as banker and custodian. The GCA appeared to be an ordinary contract for banking and custody services including holding cash deposits and securities. Sixteen accounts were established under the GCA. The securities in the accounts included UK government bonds, shares in UK listed companies and non-UK securities. ${ }^{53}$ The securities were very actively traded (6 700 trades per month over one 18 -month period).

The court considered that the cash and securities were not in use or intended for use for commercial purposes. The judge relied principally on the fact that the "overall aim of the exercise was to enhance the National Fund". In this context, the judge found that the active trading of the securities accounts, the goal of obtaining high profits at reasonable risk levels and the results-based remuneration of central bank as manager of the Fund were not determinative. The judge relied on the purpose of the securities accounts being to assist the running of the National Fund and found that "the dealings [were] all part of the overall exercise of sovereign authority by the Republic of Kazakhstan". 54

The claimants also argued that because the trading activities of the securities accounts were clearly financial transactions, they fell within the definition of commercial transactions within section 3(3) of the UK SIA. Section 3(3) notably provides that "any loan or other transaction for the provision of finance" constitutes a commercial transaction. The judge rejected the argument again on the basis of the broader purpose:

The dealings of the securities accounts must in my view be set against the background of the purpose of the GCA. That was established to assist in running the National Fund. The securities accounts contain assets which are part of the National Fund. In my view the dealings are all part of the overall exercise of sovereign authority by the Republic of Kazakhstan. ${ }^{55}$

\footnotetext{
53 Because the value of UK securities exceeded the amount of the judgment debt, the court considered that the status of the non-UK securities was irrelevant. Id. n.48.

The court also relied on a letter to the court from the Kazakhstan Ambassador to the UK. The letter recognised that the assets formed part of the Fund and beneficially belonged to Kazakhstan. However, it stated that the Fund "was designed to ensure economic stability of Kazakhstan and to accumulate funds for future generations by way of investment in securities" and that the London assets "had never been used for commercial purposes ... and [were] not intended to be used for such purposes". [Id.\$ 25] The judge noted that under SIA§ 13(5)), such certificates are to be accepted as sufficient evidence of non-commercial use unless the contrary is proved. The judge found that the only contrary evidence was the trading of the accounts and that it did not establish commercial use. (Id.§ 92)

Id. $\S 92$.
} 
Although the transactions were clearly of a nature that could be carried out by private parties, the decision does not use that approach.

The National Fund appears to be similar to a number of other SWFs. The decree creating it (and subsequent applicable rules) provided in general terms that the fund's purpose was to ensure stable social and economic development, accumulation of financial resources for future generations and reduction of the vulnerability of the economy to the influence of unfavourable external factors. The principal source of funds was earnings and taxes from the oil sector. The matters on which the funds could be spent included deficits between planned and actual revenues from raw materials, specific projects as determined by the President and set out in the State budget, and the costs of managing the Fund.

$A I G$ analysed the transactions based on their broad purpose. The nature of the activity as financial transactions was irrelevant in light of the overall purpose of earning money for the State. If the reasoning in AIG were to be adopted by other courts, SWFs would likely benefit from very broad immunity regardless of their structure. Potential claimants against an SWF would have great difficulty establishing that its activities are not for the purpose of seeking to increase the value of the fund. In contrast, as noted above, in the Sarrio case, the Swiss court expressly noted that the nature, and not the purpose, of the acts was determinative before noting that Kuwait had conceded that the underlying transactions were commercial.

The approach in $A I G$ would also make the treatment of sovereign debtors and creditors markedly different. A State that raises funds in the sovereign debt market is now generally considered to engage in private activity even if the funds are destined for immediate public purposes. ${ }^{56}$ In contrast, under the reasoning in $A I G$, investment activity by an SWF would benefit from immunity.

Overall, successfully executing against foreign state property remains difficult for private parties. As an evidentiary matter, it can be difficult to obtain information to demonstrate that property is in commercial use. Where property can be located that is in commercial use, it frequently belongs to an SOE that is a different entity than the debtor and execution is rejected on the basis that it is an independent entity.

While a unified approach to jurisdiction and execution would seem logical, the reality is that while jurisdiction has been substantially expanded, immunity from execution remains as "the last bastion of State immunity" in private law cases. There are a number of well-known cases where judgment creditors have spent many years in largely fruitless efforts in multiple jurisdictions to obtain satisfaction for judgments or arbitration awards. ${ }^{57}$ At the same time, factual data is lacking about the degree to which States evade their obligations; although States may take longer to honour their obligations, it may be the case that all but a few States do so. ${ }^{58}$ 607 (1992); UNCSI Art. 2(1)(c)(ii). 


\section{FOREIGN CENTRAL BANKS AND REINFORCED IMMUNITY FROM EXECUTION}

Central banks have been increasingly singled out for special protection with regard to immunity from execution. ${ }^{59}$ The rules in this area are of special interest for numerous reasons. First, a substantial number of SWFs are linked in some manner to their national central bank. They may be created as part of the central bank or managed by the central bank. The Santiago Principles (at p. 15) speak approvingly of the management of an SWF being delegated to an independent entity such as a central bank as one way to achieve the desired operational independence. Second, the law is evolving rapidly in this area. Two large countries (China and France) have recently adopted statutes specifically to reinforce the immunity of foreign central banks. Third, in a number of recipient jurisdictions, it appears that a central bank-related structure for a SWF would provide absolute or a very high degree of immunity to an SWF. Issues of structure can thus return to the fore. Any attempt to subject SWFs meaningfully to domestic law in all jurisdictions on an equal basis would likely have to consider the immunity of central banks.

Commentators have noted that, as in other areas, one aspect of state immunity laws in this area can be to maintain a jurisdiction's attractiveness as a financial and banking centre. In its 1984 report, the Australian Law Reform Commission cited legislative history and authoritative commentators that suggested that the special treatment of central banks under US and UK law was "at least partly motivated by the desire to protect the positions of New York and London respectively as investment centres for foreign state reserves". ${ }^{60}$ The recent changes in Chinese law apparently had in part a similar genesis. With the expansion of the central bank role with regard to SWFs, the competitive issues relating to foreign central banks may have expanded beyond attracting reserves to investment more generally.

The rules on the immunity from execution of central banks vary significantly between different jurisdictions. Many jurisdictions do not provide for special treatment for central banks; they are treated as part of the State or are assimilated to the State and are subject to the normal rules that apply to the State. As noted in the Australian Law Reform Commission report ( $\$ 132$ ), "it is hard to justify on any general principle a provision which gives foreign central banks more protection than ... foreign state[s]" themselves.

Germany and most other civil law countries generally do not provide any special treatment for central banks. A German court allowed attachment of Nigerian central bank funds in accounts in Germany in a 1975 case. ${ }^{61}$ It found that cash and securities that were not being currently used in the public service were not immune merely because they might possibly be used in the future to finance State business. The Swiss Federal Tribunal denied immunity to assets of the Libyan central bank: it rejected the argument that foreign central bank assets could in general be considered as currency reserves not subject to forced execution. ${ }^{62}$ It was also not sufficient for the State concerned, without giving any details of the designated

$59 \quad$ Central banks are generally not subject to special rules with regard to immunity from jurisdiction. Generally, if the bank is part of the State, it benefits from immunity in the same manner as the State. If it is a separate entity, it will be immune if it is engaging in sovereign acts but not if the acts are commercial.

Australia Law Reform Commission Report No. 24, "Foreign State Immunity" (1984) § 132.

Central Bank of Nigeria, Landsgericht Frankfurt, (2 December 1975), 65 ILR 131.

Libya v. Actimon SA, Swiss Federal Tribunal (24 April 1985), 82 ILR 30. 
purpose of a bank deposit held in the name of its central bank, merely to make a general declaration that the deposit was allocated for the performance of acts related to sovereign State functions.

Australia and Canada similarly do not provide special immunity for central banks. The general test applies: property used by the bank for commercial purposes is not immune.

In several major jurisdictions, however, the law provides for special protection of varying degrees for foreign central banks. The UK, US, France and China all now provide reinforced immunity for foreign central banks. ${ }^{63}$ The UNCSI also provides for special treatment for foreign central banks.

As recently interpreted in $A I G v$. Kazakhstan in relation to an SWF, the UK SIA § 14(4) provides the broadest absolute protection. ${ }^{64}$ Section 14(4) provides that, as a matter of law, the property of central banks shall not be regarded as in use for commercial purposes. ${ }^{65}$ The property is thus absolutely immune from execution as a matter of law regardless of whether it is in fact used for commercial purposes. ${ }^{66}$

The statute provides this immunity to the "property of a central bank", but does not define this concept. AIG v Kazakhstan interprets it expansively. The court found that the management of the State SWF by the central bank, as a "trust manager" under Kazakhstan law, was sufficient to give the bank a "property" interest in the fund within the meaning of the SIA provision. The existence of this central bank interest in the assets made them absolutely immune regardless of whether the SWF held the entire economic interest in the property. ${ }^{67}$

The United States FSIA also provides special protection to central banks. However, its scope is more limited than under the UK SIA as applied in $A I G$. The US FSIA exempts from execution all property of a central bank 'held for its own account'. In one case, funds in a central bank account used to finance commercial transactions of private parties were not immune because the funds were not "held for its own account." 68

A number of recent cases in the United States have rejected attempts to execute against the assets of foreign central banks on the broad ground that one legal entity (the foreign central bank) is not responsible for the debts of another (the foreign State). See, e.g., EM Ltd. v. Republic of Argentina, 473 F.3d 463 (2d

63 For convenience, the discussion refers only to central banks although the statutes also generally apply to monetary authorities.

See AIG Capital Partners Inc. and Another v. Kazakhstan, [2005] EWHC 2239 (Comm.), 129 ILR 589. As noted above, central bank immunity was an alternative basis for the court's finding of immunity.

Pakistan, Singapore and South African statutes are identical to the UK statute in this respect. See Pakistan SIA § 15(4); Singapore SIA § 16(4); South African FSIA § 15(3); Fox at p. 472.

In AIC v Central Bank of Nigeria, [2003] EWHC 1357 (2003), the court considered that "moneys in a bank account of a central bank with another bank are immune from execution irrespective of the source of the funds in the account or the use of the account or the purpose for which the account is maintained".

See $A I G \S 60$ ("In all cases, whatever the nature of the 'property' right of the central bank, the assets concerned are immune from the enforcement process".) The court referred to a "beneficial interest" of the central bank in the assets, but this was apparently a control interest rather than an economic interest. It was undisputed that under Kazakhstan law, the property held by the bank as the trust manager remained under the full ownership of the SWF, the trust founder. Id. $\S 17$. The letter from the Kazakhstan Ambassador to the court stated that the assets formed "part of the [SWF] and beneficially belong[ed] to the Republic of Kazakhstan]". Id. § 25 .

See Weston Cie de Finance et D'Investissement, S.A. v. Ecuador, 823 F. Supp. 1106 (S.D.N.Y. 1993). 
Cir. 2006); LNC Invs., Inc. v. Banco Central de Nicaragua, 228 F.3d 423 (2d Cir.2000). Accordingly, the specific FSIA provision on central banks did not need to be interpreted or applied. ${ }^{69}$

Both China and France adopted their first statutes in the area of state immunity in 2005, in both cases specifically to address foreign central banks. In China, the law was reportedly prompted by a request from Hong Kong to maintain the absolute immunity for foreign central bank assets that applied under UK law in order to maintain Hong Kong's status as an international financial centre. ${ }^{70}$ The law provides for absolute immunity from execution for the property of central banks and law applies to mainland China and the Macau Special Administrative Region as well as to Hong Kong. ${ }^{71}$ The law contains a reciprocity provision allowing for the provision of less immunity. ${ }^{72}$

The Chinese law applies to the property of the central bank. A definition illustrating the concept is provided in art. 2 ("For the purposes of this Law, the property of foreign central banks includes the cash, notes, bank deposits, securities, foreign exchange reserves and gold reserves of the foreign central banks and the banks' immovable property and other property".)

France's 2005 legislation provides stronger but not absolute immunity to central banks. It extends broadly to property "held or managed" by the central bank on behalf of the foreign State ("leurs biens de toute nature [qu'elles] ... détiennent ou gèrent pour leur compte ou celui de l'Etat ou des Etats étrangers dont elles relèvent"). ${ }^{73}$ It would thus apply to State SWF funds managed by a central bank.

Immunity is provided in principle for all such central bank or State assets held or managed by the central bank. However, a narrow commercial/private act exception exists. Execution is available if is established that the property is part of "a patrimony used for a principal activity of a private law nature" ("les biens font partie d'un patrimoine [affecté] à une activité principale relevant du droit privé"). The legislation thus applies to central banks the test adopted by the Cour de Cassation in the Sonatrach case for SOEs. However, whereas in the case of a State-owned commercial company such as Sonatrach most if not all of its assets would normally be in commercial use, the core functions of a central bank are normally

69 In $E M$, the Argentine central bank was a separate juridical entity from the Republic of Argentina and the court noted that US law applies a presumption of independent status for separate corporate agencies or instrumentalities. The court underlined that the plaintiffs had not argued that the presumption should be set aside. The court also found that the use of the property -- repayment of government debt to the IMF -- was not a "commercial activity" so that the assets would have been immune in any event.

Another case also brought by EM Ltd. and others in the United States does seek to overcome the presumption of separate status for the Argentine central bank. EM has argued that the bank's assets should be made available to satisfy claims against the Argentine state on the grounds that the bank is allegedly the alter ego of the state; the case had not yet been decided as of February 2010.

Fox at p. 472.

See Law of the People's Republic of China on Judicial Immunity from Measures of Constraint of the Property of Foreign Central Banks (adopted 25 October 2005). China's 2008 argument in FG Hemisphere, supra, that it has always endorsed absolute immunity could arguably have been challenged not only on the basis that it is inconsistent with China's support for UNCSI but also with its adoption in 2005 of a special law providing only for the absolute immunity of central banks. This latter issue, however, was not addressed in FG Hemisphere.

The only exceptions are a written waiver or allocation by the foreign State of the property to be used for attachment and execution.

See article 51 of Law No. 2005-842 of 26 July 2005, adding art. 153-1 to the Monetary and Financial Code. The reference to a central bank depending on several States would appear to apply to the European Central Bank. 
sovereign. The notion of an "activité principale relevant du droit privé", as applied to central banks, will thus require interpretation.

Article 21 of the UNCSI in effect provides that the "property of a central bank" (or other monetary authority of a State) shall not be considered to be in commercial use and its language is thus similar to the UK statute. It thus provides absolute immunity from execution for such property. The $A I G$ court relied notably on the UNCSI to find that absolute immunity for central banks is considered to be legitimate in the eyes of the international community. However, it is not clear whether the notion of "property of a central bank" in the UNCSI will be interpreted in the same manner as was UK law in AIG. 


\section{STATE IMMUNITY IN CRIMINAL PROCEEDINGS}

This section of the note begins the review of state immunity principles in cases involving host state regulation. Unlike most private lawsuits, regulatory regimes frequently provide for possible penalties such as fines (and not just compensation) or involve enforcement of the law by a public agency rather than a private party. This part begins the analysis by examining criminal proceedings, the most coercive form of regulation.

The general trend towards a restrictive theory of immunity in civil or private law matters has not to date been evident with regard to criminal jurisdiction over foreign states in particular because of the sanctions at issue. Hazel Fox, a leading commentator, considers that the general rule remains one of absolute immunity:

The plea [of state immunity] is generally discussed in relation to civil proceedings, although it also serves as a bar to criminal proceedings. Unlike civil proceedings, the rule relating to immunity of a foreign State in respect of criminal proceedings in another State remains generally absolute. The outcome of criminal proceedings is the imposition of a penalty or imprisonment on the defendant. Such enforcement measures against another State could bring the forum State into direct confrontation with the foreign State, and the avoidance of such situation remains a strong incentive for the maintenance of absolute immunity from the criminal jurisdiction of the forum State. ${ }^{74}$

In Pinochet (No. 3), the House of Lords was unanimous that their decision (rejecting Pinochet's personal plea of immunity) preserved the absolute immunity which a State enjoys from criminal proceedings before national courts. ${ }^{75}$ In Jones v. Ministry of Interior of Saudi Arabia, Lord Bingham, giving the leading judgment of the House of Lords, stated that "[a] state is not criminally responsible in international or English law, and therefore cannot be directly impleaded in criminal proceedings. ${ }^{176}$ In civil law countries, it has been similarly generally been recognised that the restrictive theory does not apply to criminal proceedings. ${ }^{77}$

As Fox notes, the general acceptance that a foreign State enjoys absolute immunity from national criminal proceedings "has been largely unquestioning, with little inquiry into the nature, reason, and scope of such immunity from criminal jurisdiction" ${ }^{78}$

74 See Hazel Fox, The Law of State Immunity, October 2008, Oxford University Press, at p. 33; see id. at p. 91 ("The adoption of a restrictive doctrine has not been treated as having any relevance in relation to the absolute immunity of the foreign State from criminal proceedings ....")

See R. v. Bow Street Metropolitan Stipendiary Magistrate, ex parte Pinochet Ugarte, (Pinochet (no.3)), [2000] AC 147; Fox at p. 249-250.

Jones v. Ministry of Interior of Saudi Arabia [2006] UKHL 26. This approach frames the issue as one of the nature of State responsibility (which cannot be criminal) rather than as an immunity.

Fox at p. 85 
Criminal law has been excluded from the scope of the multilateral conventions on state immunity. In its resolution adopting the draft UNCSI, the UN General Assembly accepted "the general understanding of the ad hoc Committee that the convention does not cover criminal proceedings". ${ }^{79}$ The ECSI does not apply in cases involving penalties or fines and is generally limited to private law cases.

National statutes on state immunity also generally exclude criminal proceedings from their scope. In the UK, for example, the SIA does not apply to criminal proceedings. Immunity from criminal proceedings is governed by the common law and customary international law. The Australian and Canadian statutes also do not apply to criminal proceedings. ${ }^{80}$

Where no international convention or national statute applies, the issue remains subject to customary international law. Fox has suggested that the application of the restrictive theory to foreign state entities in private law cases may provide a basis for development of a limited exception to immunity for certain criminal proceedings:

The[] development[] [of the restrictive theory] in civil jurisdiction might indirectly point the way, should occasion so require, to the fashioning of an exception to immunity from criminal proceedings. If the alleged act took place within the forum state's territory, if the proceedings are based on infringements of a commercial or private law nature, and the infringement constitute municipal crimes but are capable of generating civil duties of reparation and the remedy is restricted to such reparation, is there any objection to introducing an exception to the immunity for the consequences of such crimes on the same lines as for civil proceedings ${ }^{81}$

As the author notes, a number of factors would strengthen the case for this occurring: the limitation of remedies to compensatory type remedies; the commercial nature of the transaction; and a strong jurisdictional (territorial) connection of the events with the forum state.

The law in this area remains uncertain, including in its application to SWFs and state-controlled enterprises. As in any area where the law may still apply absolute immunity, the issue of the precise contours of the definition of the state would be of great importance in any criminal proceedings. If an enterprise does not form part of the foreign state under applicable law, it would be unlikely to benefit from immunity unless it is carrying out governmental functions.

$79 \quad$ UNGA Res. 59/38 (2005), adopted without a vote.

See Australian FSIA s. 3; Canadian SIA s. 18. It also appears that the US FSIA, which is silent on sovereign immunity in the criminal context, excludes criminal proceedings from its scope, but the issue appears not to have been definitively resolved.

See Fox at 92-93. 


\section{STATE IMMUNITY WITH REGARD TO TAXATION}

Although it is a technical area of the law, tax is an important area to review with regard to the application of state immunity. There is substantial national government administrative practice relating to state immunity (although commentary remains scarce). In addition, taxes and exemptions there from can also obviously be critical factors in investment decisions by sovereign wealth funds.

State immunity in tax matters is examined by reviewing the key international instruments and then some examples of how countries have treated issues of state immunity, if any, raised by investments by foreign government-related investors.

\section{Multilateral international instruments \\ a. The ECSI}

The ECSI (art. 29) expressly excludes proceedings for taxes from the operation of the Convention. The Commentary ( $\$ 113)$ notes that the Convention "is essentially concerned with 'private law' disputes between individuals and States". Customs duties, taxes and penalties are expressly excluded.

\section{b. UNCSI}

The area of tax was excluded from the scope of the Convention. During the preparatory work by the ILC, a draft article was prepared specifically addressing tax. It provided for a general exclusion of sovereign immunity from jurisdiction for tax purposes unless otherwise agreed by the States concerned. The draft article was provisionally adopted by the ILC at its thirty-sixth session (1984) in the following terms:

Unless otherwise agreed between the States concerned, the immunity of a State cannot be invoked before a court of another State which is otherwise competent in a proceeding which relates to the fiscal obligations for which it may be liable under the law of the State of the forum, such as duties, taxes or other similar charges. ${ }^{82}$

The draft article did not distinguish between commercial and non-commercial acts or transactions. The provision addressed only immunity from jurisdiction and was not intended to affect immunity from execution.

The draft article, however, was subsequently deleted from the ILC Draft Articles before they were finalised in 1991. The deletion was sought on the ground that an article which dealt with inter-State relations alone was not considered to have its proper place in a convention dealing with relations between States and private parties. If left in the treaty, it would violate the principle of sovereign equality of States by allowing a State to institute proceedings against another State before the courts of the former State. ${ }^{83}$

82 See [1986] Yearbook of the ILC, vol. II (part 2), p.11 \& n.23 (art. 16).

83 See ILC Commentary, Commentary on Article 10 (Commercial transactions) $§ 12$. 
There were members, however, who opposed the deletion of the article. They noted that it was based on extensive legislative practice and had been adopted on first reading. ${ }^{84}$ After some discussion, it was finally decided to delete the draft article on the understanding that the commentary to article 10 would clarify that its deletion is "without prejudice to the law with respect to fiscal matters". Accordingly, the final 1991 ILC draft did not include a specific provision on tax.

The final 2004 Draft Convention, which was largely based on the 1991 ILC Draft Articles, does not include an express provision on tax. The preamble to the 2004 Draft Convention provides that customary international law continues to govern areas not regulated by the Draft Convention. It would appear that tax matters are generally excluded from UNCSI and are subject to customary international law.

$c$.

\section{OECD Model Tax Convention}

The OECD Model Tax Convention provides a means of settling on a uniform basis the most common problems that arise in the field of international double taxation. ${ }^{85}$ It also deals with other issues, such as tax evasion and non-discrimination. ${ }^{86}$

While the Model Convention does not expressly address state immunity from tax as such, its provisions are of interest for several reasons. First, the Model Tax Convention generally extends to a foreign State itself the benefits that tax conventions grant to private residents of that State. This is achieved by extending the definition of "resident of a contracting State" to the State itself. ${ }^{87}$

Categorization of the foreign State as a resident of that State in effect recognises the foreign State as a potential taxpayer in the other State. The articles in the Convention define the jurisdiction(s) with taxing power over various types of income with regard to residents of one or both States. Thus, for example, Article 10 provides that dividends payable by a company resident in one Contracting State to a "resident of the other Contracting State" may be taxed in both States subject to a limitation on the applicable tax in the source State. For purposes of the Model Convention, these provisions apply in the same manner to State and private entities. ${ }^{88}$ Accordingly, claims for treaty benefits would be made on the same basis as those of private entities and not based on any sovereign status.

$84 \quad$ The legislation cited by the ILC, such as the UK SIA, did not generally go as far in removing immunity as the proposed provision. (See below for a discussion of examples of national policies. ).

OECD Model Tax Convention on Income and on Capital, Condensed version ("OECD Model Tax Convention"), Introduction $\S 3$.

Id. § 16 .

Article 4(1) of the Convention thus provides that "for purposes of this Convention, the term 'resident of a Contracting State' ... includes that State and any political subdivision or local authority thereof". The Commentary (para. 8.4) clarifies that this change to the Model Convention in 1995 was meant to conform the Model to "the general understanding of most member countries ..." OECD Model Tax Convention, Art. 4(1) and Commentary on Article 4 para. 8.4. Accordingly, it applies more generally than merely to treaties based on the post-1995 Model Convention.

The reservations to Article 4 do not apply to the provision making the foreign state a resident for tax purposes. See id. Commentary on Article 4 at paras. 27-32. The UN Model Tax convention is also identical in this respect to the OECD Convention. The Commentary to the UN Convention reproduces the OECD Commentary and notes that the UN Model Convention was amended in 1999 to add the express provision clarifying that the government of each State is a resident of that State for purposes of the Convention.

See Art. 1 ("This treaty shall apply to persons who are residents of one or both of the Contracting States".) 
Second, it is noteworthy that the only express reference to immunity in the Model Tax Convention and Commentary involves a clarification of an instance where no immunity is required for foreign state entities. The commentary to the non-discrimination principle in Article 24(1), which generally prohibits discrimination of the basis of nationality, makes clear that Art. 24(1) does not require that grants of immunity to domestic government entities be also granted to foreign state entities. ${ }^{89}$

The Model Convention (art. 28) also expressly excludes any application of the Convention that would affect the fiscal privileges of members of diplomatic missions or consular posts under the general rules of international law or under the provisions of special agreements. There is no similar provision with regard to State immunity generally.

\section{2. $\quad$ National policies}

The primary focus here is on the treatment of state immunity under domestic tax law rather than on any specific grants of immunity to particular countries in bilateral tax treaties. This area is most relevant for drawing broader conclusions about state immunity with regard to host state regulation generally. ${ }^{90}$

$a$.

Substantive exemption or procedural immunity?

Exclusion of foreign state liability from tax can be achieved either as a substantive exemption from tax liability or as a jurisdictional or procedural immunity from suits to collect tax (or both). The difference in approach could have significant consequences due, for example, to the rules on withholding taxes. Residents are frequently required to withhold taxes from payments to non-resident taxpayers. The government may obtain those funds without the need for court proceedings.

For those countries that recognise some limitations on foreign state liability for tax, it appears that most if not all have established substantive exemptions from taxes. As discussed below, France and the United States grant substantive exemptions from tax. The 1984 Australian Law Commission Report recommended that any exemptions from tax should be resolved in substantive tax legislation rather than being achieved by the procedural device of an immunity from suit. ${ }^{91}$ It considered that "it cannot be assumed that the general rules delimiting foreign state immunity from civil proceedings are an appropriate criterion for subjecting foreign states to taxation". ${ }^{92}$ It did not suggest any alternative criterion and recommended that the tax authorities make decisions about which taxes should apply to foreign sovereigns.

OECD Model Tax Convention on Income and on Capital, Condensed version, Art. 24 and Commentary on Article 24 para. 10 and 12. Paragraph 10 states that Article 24(1) is "not to be construed as requiring a State that accords special tax privileges to its own public bodies or services as such, to extend the same privileges to the public bodies and services of the other State." Paragraph 12 further clarifies that "if a State accords immunity from taxation to its own public bodies and services, this is justified because such bodies and services are integral parts of the State and at no time can their circumstances be comparable to those of the public bodies and services of the other State". However, State corporations carrying on gainful undertakings on the same footing as private undertakings would be subject to paragraph 24(1). Accordingly, if a State accords immunity to such undertakings, it arguably would have to accord similar immunity to foreign ones under Art. 24(1).

The actual tax burden on SWFs in different jurisdictions, which obviously can depend critically on special provisions in bilateral tax treaties, is not addressed here.

See Australia Law Reform Commission Report No. 24, "Foreign State Immunity" (1984) § 112 ("if a foreign state ought not to be taxed in a particular way, this should be reflected in the substantive taxation legislation rather than being achieved indirectly through a procedural immunity").

Id. $§ 112$ n.97. 
Even where the exclusion from tax is primarily defined in substantive tax law, procedural immunities may remain relevant with regard to any taxes that are payable. The Australian Law Reform Commission made clear that its consideration of tax issues was limited to civil proceedings to recover tax. For example, the immunity of foreign states from execution could still be raised, as could jurisdictional immunities from criminal proceedings.

The scope of procedural immunities from applicable tax can raise delicate issues. In a recent case, the United States Supreme Court addressed the issue of tax liens arising from allegedly unpaid taxes on foreign-state-owned immovable property. ${ }^{93}$ While a lien does not directly collect tax, the amount of a valid lien is notably collectable from any third-party purchaser of the property before any proceeds are transferred to the foreign state. The US government filed an amicus brief in support of immunity, but the court denied immunity on the ground that tax liens fell within the FSIA exception to immunity for cases involving rights in immovable property located within the forum state. The court found that the FSIA exclusion relating to immovable property was broader than in the ECSI and that it permitted tax liens.

b. Selected national approaches to foreign state liability for taxes on passive income under domestic tax law

Passive income is an area of particular importance for sovereign wealth funds. This section relies in part on a recent comparative survey on the "Taxation of the Passive Income of Foreign Governments and Sovereign Wealth Funds in Selected Foreign Countries" by the Law Library of Congress, which is appended to the Report "Economic and U.S. Income Tax Issues Raised by Sovereign Wealth Fund Investment in the United States", prepared by the Staff of the US Joint Committee on Taxation. ${ }^{94}$ The countries surveyed are: Australia, Canada, Germany, Japan, Norway, Poland, Switzerland and the United Kingdom.

Overall, although all of the countries under review apply the restrictive doctrine in private law matters, there is a pronounced diversity of treatment of foreign states with regard to immunity from tax. All three possible positions are represented: (1) treatment like private investors; (2) an exemption limited to non-commercial investments; and (3) a broad exemption applicable to all investments. Less surprisingly, there are some differences in what is defined as commercial among countries that apply that approach; these differences, however, pale in comparison to the overall diversity of approach.

Other differences exist at the level of the policy method employed. Some countries clearly define a general approach by law or regulations; others have proceeded by establishing policies. The degree of administrative discretion also varies significantly.

Countries that do not exempt foreign governments from taxation of passive income include Germany, Norway, Poland, and Switzerland. Germany taxes foreign governments, including SWFs, in the same manner as foreign corporations. According to the recent US report cited above, Germany's view that

93 See Permanent Mission of India to the United Nations v. New York, 551 U.S. 207 (2007). The taxes allegedly applied to the parts of a building that were used to house diplomats and other employees (at a rank below that of Permanent Resident or Consul General) from the Permanent Mission of India to the United Nations. The State of New York contends this part of the property is taxable under New York law while India contends that the property is exempt from tax under the Vienna Convention on Diplomatic and Consular Relations. Because the case involved a motion to dismiss on jurisdictional grounds, the issue of substantive tax liability was not addressed.

Reports by the Law Library of Congress are research materials and do not constitute official positions of the United States government. The Committee Report and appendix are available at http://www.house.gov/jct/x-49-08.pdf. 
sovereign immunity does not apply is strongly influenced by article 4(1) of the OECD Model Convention. ${ }^{95}$ The domestic tax laws of Norway, Poland and Switzerland similarly do not appear to include any special provision for foreign governments with regard to tax on passive income.

Australia, Canada and the United States generally exempt only non-commercial investments. Australia has a long-standing practice of exempting passive investments by foreign governments from tax on an administrative basis. ${ }^{96}$ There is no legislation establishing this exemption, but the criteria have been defined in an interpretive notice. Australia generally limits the exemption to non-commercial transactions (with 10 percent or less equity ownership being a guidepost for defining a non-commercial activity). On 20 August 2009, the Australian Treasury announced that legislation (originally announced in 2005) on state immunity from tax would be introduced shortly. The proposed changes are intended to provide greater certainty to foreign governments investing in Australia by codifying existing practice under which foreign government income from passive portfolio investments such as interest, dividends and managed funds distributions is not subject to tax. Income from commercial activities will continue to be subject to Australian tax..$^{97}$

Australia has also sought to coordinate its foreign investment review process and tax law with regard to foreign states. Its policy on commercial investments by foreign governments is, as articulated by the Foreign Investment Review Board, to require "...commercial investments by foreign governments or their agencies to be structured in a manner that enables all normal taxes and charges to be levied, and avoids questions of sovereign immunity arising". ${ }^{98}$ Because all investments by foreign government-related entities must be reported under longstanding policy, the applicable principles are made clear from the outset.

In Canada, there are no express provisions on tax matters in the Canadian SIA. Nor is there a exemption for foreign states in the Income Tax Act. However, Revenue Canada has a policy, disclosed in an Information Circular, that allows the government to grant relatively narrow exemptions from withholding for certain non-commercial transactions (interest on arm's length debt or portfolio dividends on listed company shares) on a reciprocal basis. ${ }^{99}$

The United States also limits the exemption to non-commercial transactions, but the definition of noncommercial transactions is in some respects quite broad. The US FSIA does not include any provision relating specifically to tax, but a long-standing tax exemption from US income tax applies to certain noncommercial passive income received by foreign governments. See 26 U.S.C. $\$ 892$. The definition of noncommercial transactions is in some respects broader than in other countries. In particular, income from investments in companies in which the State holds less a 50\% (and noncontrolling) interest is defined as

$95 \quad$ See US Law Library report at A-30.

This applies alongside the statutory and regulatory approach to tax exemptions adopted after the Law Commission report discussed above.

See Greater Certainty for Sovereign Investments, Australia Treasury (20 August 2009), available at http://assistant.treasurer.gov.au/DisplayDocs.aspx?doc=pressreleases/2009/033.htm\&pageID=003\&min=nj sa\&Year=\&DocType.

See Guidelines for Foreign Government Investment Proposals, Attachment A to Australia's Foreign Investment Policy (March 2009), available at http://www.firb.gov.au/content/_downloads/australia's\%20foreign\%20investment\%20policy.pdf.

See also Treasurer's Press release of 17 February 2008 http://www.treasurer.gov.au/DisplayDocs.aspx?doc=pressreleases/2008/009.htm\&pageID=\&min=wms\&Y ear $=\&$ DocType $=0$.

Revenue Canada Agency, IC77-16R4, s. 50,

http://www.cra-arc.gc.ca/E/pub/tp/ic77-16r4/ic77-16r4-e.html (last visited 19 May 2009). 
non-commercial. Other exempted income includes the holding of bank deposits in banks and trading for a foreign government's own account.

In addition to section 892, a special rule ( $(895)$ exempts from U.S. tax certain income derived by a foreign central bank from U.S. government obligations or from interest on bank deposits. The exemption applies to an instrumentality that is separate from a foreign government, whether or not owned in whole or in part by a foreign government. The exemption does not apply (1) if the foreign central bank of issue does not own the obligations or bank deposits, or (2) if the obligations or deposits are held for, or used in connection with, the conduct of commercial banking functions or other commercial activities.

A third approach involves a broad immunity from tax liability for direct taxes. ${ }^{100}$ UK tax policy, for example, exempts foreign States from all liability for income tax and other direct taxes. ${ }^{101}$ The International Manual of the tax authorities states that based on sovereign immunity, "current UK practice is to regard as immune from direct taxes all income and gains which are beneficially owned by the head of state and the government of a foreign sovereign state recognised by the UK". ${ }^{102}$ The exemption applies broadly to both commercial and non-commercial transactions. It also applies to both portfolio and controlling investments.

According to the Library of Congress report, Japan apparently exempts foreign governments from taxation on interest in bank deposits and apparently on dividends by administrative practice.

French law appears to apply a mixed approach. Foreign state income from portfolio investments is generally exempt by law. ${ }^{103}$ The law does not use the non-commercial criterion, but the result is similar to those States that limit the exemption to portfolio investments using a non-commercial criterion. However, while the general rule limits the exemption to portfolio investments, the Ministry of Finance can grant total exemptions. The criteria for such complete exemptions are not specified. ${ }^{104}$ Thus, France can apply either a limited or complete exemption.

As in other areas, tax authorities that exempt foreign states from tax liability under domestic law must determine which foreign-state-related entities will benefit from the exemption. For those States that recognise some sovereign immunity with regard to tax, a variety of approaches are also taken to the definition of the foreign state.

100 Direct taxes are generally considered to be taxes imposed on income, capital gains and net worth. Gift tax, death duties and property tax are also considered to be direct taxes. OECD Glossary of Tax Terms, http://www.oecd.org/document/29/0,3343,en_2649_34897_33933853_1_1_1_1,00.html\#D.

101 The UK SIA excludes immunity for proceedings relating to certain indirect taxes. Other taxes, including income tax and other direct taxes, are outside the scope of the SIA and remain subject to the common law. See R. v. Inland Revenue Commissioners, ex parte Camacq Corp., [1989] 1 British Tax Cases 480 (reporting both the Divisional Court and Court of Appeal decisions), 103 ILR 327 (CA decision only).

102 See http://www.hmrc.gov.uk/manuals/intmanual/intm155010.htm (last visited 1 May 2009). The International Manual contains up to date guidance for HM Revenue \& Customs staff on key international tax issues.

104 Income from direct investments, as defined to include those involving control, is taxable in principle, but the Ministry of Finance can grant special exemptions or reductions. [CGI arts. 244 bis A I(1), 244 bis B, 244 bis C]. 
Australia appears to generally require that the agency be "owned and controlled by the government and [that it] not engage in commercial activities". ${ }^{105}$ In Australia, an SWF may obtain an exemption only by establishing that the passive investment income that will be eligible for the exemption results from the performance of a governmental function in Australia.

According to the US report, Canadian tax authorities have reportedly indicated that with regard to SWFs, evaluation of eligibility for the exemption is based on whether their purpose is public/humanitarian or commercial. It is unclear whether this analysis is a general one for the SWF as a whole or transactionspecific. The applicable criteria with regard to ownership, control or integral part requirements are not clear.

In France, CGI Article 131 sexies establishes a complex regime that distinguishes between four types of foreign state-related entities: foreign states, central banks, foreign public institutions and foreign public financial institutions. As noted above, foreign states and central banks benefit from a statutory exemption from taxes on passive income, subject to an exception for direct investments (which can be lifted). Generally, foreign public institutions and foreign public financial institutions do not appear to benefit from any statutory exemptions, but can be exempted to varying degrees by the Ministry of Finance. ${ }^{106}$

The 2008 study indicated that in Japan SWFs were not considered to benefit from state immunity and were taxable under domestic law in the same manner as a foreign corporation.

In the UK, a recent government statement in Parliament in response to a written question about the treatment of SWFs indicates that the policy requires that the entity constitute an "integral part" of the government in order to benefit from the exemption. ${ }^{107}$ This appears to be long-standing government policy. Under the integral part test, legal entities separate from the government have been excluded from the exemption even if the government owns all of the share capital. This distinction apparently played an important role in a tax dispute with Kuwait government-related entities, including a sovereign wealth fund, that arose over tax-exempt income from the ownership of a $21.7 \%$ stake in British Petroleum in the late 1980s and early 1990s.

News reports indicated that by 1993 Inland Revenue had apparently refunded over GBP 600 million in tax to KIO, a sovereign wealth fund that was considered to be an integral part of the Kuwaiti government, relating to income from the shares. ${ }^{108}$ The reports indicated that evidence subsequently arose, in the context of ongoing litigation, that the shares had been purchased by the Kuwait Petroleum

$105 \quad$ Australian Tax Office Interpretive Decision 2002/45.

106 Definitions for the terms foreign public institution and foreign public financial institution have not been located. The criteria for exemptions or reductions are also not specified in the law.

House of Commons debates (28 Apr. 2008), column 143W (Statement by Exchequer Secretary to the Treasury: "Where a sovereign wealth fund is an integral part of the government of a foreign sovereign state it will benefit from immunity from UK tax. As a result of this immunity no taxation will have been received from sovereign wealth funds. The United Kingdom recognises the principle of international law known as sovereign immunity whereby one sovereign state does not seek to apply its domestic laws to another sovereign state. In accordance with this principle, current UK practice is to regard as immune from direct taxes all income and gains which are beneficially owned by the head of state and the government of a foreign sovereign state recognised by the UK.").

According to news reports, this included a payment of approximately GBP 450 million which the Inland Revenue made to the KIO in the spring of 1989. This was part of a complex transaction by which BP bought back more than half the stake from the Kuwaiti entity. This followed the Monopolies and Mergers Commission report finding that such a large stakeholding by a foreign government was against the British public interest. The UK government required KIO to reduce its holding to 9.9 per cent. 
Corporation (KPC), the national oil company, and not by KIA/KIO, as had been originally claimed. ${ }^{109} \mathrm{KPC}$ was apparently considered to be a commercial company rather than an integral part of the government. Inland Revenue apparently conducted a lengthy formal investigation but the outcome is unknown. ${ }^{110}$

In the United States, SWFs may benefit from the exemption. For purposes of section 892, a foreign government includes the "integral parts" and "controlled entities" of a foreign sovereign. It would appear that, absent unusual circumstances, SWFs will generally constitute either an integral part or a controlled entity of a foreign sovereign for purposes of section $892 .{ }^{111}$ The notion of controlled entity would appear to apply more broadly to many wholly state-owned companies, including, contrary to the recent holding in Dole with regard to the FSIA, to indirectly-owned companies.

It appears that state policies on sovereign immunity from taxes on passive income vary greatly within OECD Roundtable countries. Of the countries reviewed above, a number do not appear to provide any immunity for foreign sovereigns, others apply a restrictive theory excluding taxes arising from commercial transactions (as defined in differing ways), and two countries provide absolute immunity from direct taxes. Of course, as noted above, these approaches under domestic law do not necessarily reflect the actual tax treatment; in some cases, tax treaties may provide for immunity, including for specific entities.

Although the draft provision on tax in the ILC draft articles - which excluded all immunity with regard to tax on foreign States except where otherwise agreed by the States concerned - was eliminated prior to completion of the $1991 \mathrm{draft}$, the elimination was based on the limited scope of the UNCSI. There was substantial support for the substance of the proposed provision at the ILC. In determining whether one approach or the other among those currently employed by various countries is more consistent with the requirements of international law, it could also be important to determine if foreign states have objected to the absence of immunity or limited immunity granted by a number of countries. It is possible that sovereign investors vote with their feet and select more tax-favourable jurisdictions.

\footnotetext{
109 Peter Bruce and Robert Peston, "Kuwait misled UK over buyer of \$1.7bn BP stake", Financial Times (24 September 1993). response to questions raised in Parliament, the government indicated that information about the affairs of specific taxpayers is confidential.

111 "Integral part" is broadly defined and includes, inter alia, any person, body of persons, organization, agency, bureau, or fund that constitutes a governing authority of a foreign country, but does not include any individual who is acting in a private or personal capacity. Moreover, no portion of the earnings of the governing authority may inure to the benefit of any private person. A "controlled entity" is any entity separate in form from a foreign sovereign that satisfies four requirements. The separate entity must (1) be wholly owned and controlled (directly or indirectly) by the foreign sovereign; (2) be organized under the laws of the foreign sovereign by which it is owned; (3) have its net earnings credited to its own account or to the accounts of the foreign sovereign, with no portion inuring to the benefit of any private person; and (4) have its assets vest in the foreign sovereign upon dissolution. A separately organized pension trust can qualify as a controlled entity under certain conditions. See 26 CFR $\S 1.892-2 T$ (a) (temporary regulations).
} 


\section{STATE IMMUNITY AND COMPETITION LAW}

This section of the note addresses some state immunity issues in the area of competition law. At this stage, the discussion is primarily limited to the US and EU, the two most active systems of competition law enforcement with the broadest international reach. The major types of remedies and proceedings are briefly reviewed under each system before practice with regard to state immunity is examined. This section also reviews the decision of the UK government, following a Monopolies and Mergers Commission report, to require partial divestment of a Kuwaiti State-controlled investment in British Petroleum Company plc.

\section{United States}

Antitrust law in the United States provides for a wide variety of public and private suits seeking a broad array of remedies; the line between public law and private law is unclear. Because of the importance of remedies in the law of state immunity, a brief overview is provided of the principal remedies and proceedings before turning to the application of state immunity.

\section{a. Overview of principal available remedies and proceedings}

Section 1 of the Sherman Act condemns contracts, combinations, and conspiracies in restraint of trade. Section 2 sanctions monopolization, attempted monopolization, and conspiracies to monopolize. The provisions are framed as criminal laws with offenses punishable by imprisonment and fines, but under long-established judicial construction and federal enforcement practice, the range of conduct that is prosecuted criminally is limited to traditional per se offenses, including price-fixing, customer allocation, and bid-rigging. Accordingly, as permitted by other sections of the Sherman and Clayton Acts, federal antitrust enforcement actions are often civil actions and permit both private as well as government causes of action. ${ }^{112}$ Every violation appears to permit possible civil and criminal, legal and equitable, and private as well as public actions. The provisions authorising non-criminal lawsuits generally speak simply of antitrust "violations" without further definition. Key provisions authorising lawsuits for violations include Sherman Act $\S 4$ and Clayton Act $\S 15$ (equitable relief, including through government suits); Clayton Act $\S 16$ (allows private persons to obtain injunctions against actual or threatened antitrust injury); Clayton Act $\S 4$ (treble damages for private parties). Neither regulators nor the courts can impose civil fines for violations of the Sherman Act. ${ }^{113}$ (As discussed below, this contrasts with the situation in the European Union where substantial civil fines are a frequently-used sanction both for cartels and abuse of dominant position.) The antitrust laws apply to persons and thus to both individuals and companies.

The primary types of court actions brought by public agencies are criminal suits and civil suits seeking equitable relief. As noted, civil fines are not available as a remedy for violations of the Sherman Act. ${ }^{114}$ Government civil suits seeking equitable relief can give rise to a very broad range of court orders to prevent repetition of violations or to seek to restore competitive conditions. For example, a monopolist

\footnotetext{
112 Violations of the Clayton Act and the Federal Trade Commission Act are not crimes.

113 Other sections of the federal antitrust laws provide for civil penalties: for example, the Justice Department can seek civil penalties for violations of the pre-merger notification provisions.

114 Other sections of the federal antitrust laws provide for civil penalties: for example, the Justice Department can seek civil penalties for violations of the pre-merger notification provisions.
} 
can be split apart and restrictions placed on the post-break up businesses in which it can engage; pricing practices can be controlled; dealings with suppliers or competitors can be regulated, and the company can be subject to continuing obligations to disclose sensitive information. ${ }^{15}$

Private parties have a fundamental role in enforcing the US antitrust laws. The remedies for private parties go beyond merely compensating them for losses incurred. The statutes mandate recovery of triple the amount of injuries sustained "by reason of anything forbidden in the antitrust laws", including the Sherman and Clayton Acts. This "treble damages" remedy deliberately over-compensates the plaintiff for his/her injuries and (together with other measures such as the rules on legal costs) gives private persons a powerful financial incentive to enforce the law. In a well-known phrase, private parties are said to act as "private attorneys-general". Private parties are also empowered to seek equitable relief.

\section{b. $\quad$ Application of state immunity}

The FSIA does not expressly address its application to the antitrust laws as such. The issue does not appear to have been addressed with regard to criminal cases in the antitrust area.

The FSIA excludes punitive damages against foreign states, but not against state instrumentalities (including state-owned companies). ${ }^{116}$ Treble damages awarded in private antitrust suits go beyond compensation and could thus be considered to be punitive damages or penalties. Fines on SOEs would thus seem possible under U.S. law, but as noted above, the antitrust authorities generally do not have the power to impose civil fines in Sherman Act cases. .

The Antitrust Enforcement Guidelines for International Operations, issued by the DOJ and FTC in 1995 , briefly address state immunity. They state (§ 3.31) that "[a]s a practical matter, most activities of foreign government-owned corporations operating in the commercial marketplace will be subject to U.S. antitrust laws to the same extent as the activities of foreign privately-owned firms". A number of civil cases have applied the antitrust laws to SOEs or foreign trading organisations by finding that the activity at issue was commercial. ${ }^{117}$

Alleged price-fixing by OPEC and OPEC member states has been the most prominent context for the consideration of state immunity relating to antitrust in the United States. In International Association of Machinists (IAM) v. OPEC, a union brought a price-fixing suit against OPEC and its 13 member States seeking injunctive relief and damages. ${ }^{118}$ (The claim for damages was excluded early in the case on substantive grounds because IAM was only an indirect purchaser of the oil. OPEC was also dismissed from the case at an early stage after the court determined that it had not been properly served with process.) The defendants did not appear in the proceedings in the district court, but their case was argued by various

115 The Federal Trade Commission is authorised to issue cease and desist orders, which are similar to a judicial injunction. These carry no criminal or civil penalties for past conduct and do not assess damages. In a manner similar to a judicial injunction, they primarily seek to undo unlawful action and prevent further unlawful action.

116 As discussed above, many States other than the US treat independent SOEs as private entities.

$117 \quad$ See American Bonded Warehouse Corp. v. Compagnie nationale Air France, 653 F. Supp. 861 , 864 (N.D. Ill. 1987) ([alleged scheme to eliminate competition in the freight forwarding industry constituted commercial activity); Outboard Marine Corp. v. Pezetel, 461 F. Supp. 384 (D. Del. 1978) (manufacture and sale of golf clubs by Polish government trade organisation was commercial).

International Association of Machinists (IAM) v. OPEC, 477 F. Supp. 553 (C.D. Cal. 1979), 63 ILR 284, aff'd, 649 F.2d 1354 ( $9^{\text {th }}$ Cir. 1981), 66 ILR 413, cert. denied, 454 U.S. 1163 (1982). 
amici, with additional information provided by court-appointed experts, in order to allow the court to rule on immunity on its own motion, as required by the FSIA.

Both the district court and the appellate court found that the action should be dismissed, but for different reasons. The district court held that OPEC and its members were protected by immunity because their actions in collectively setting pricing targets and implementing their decisions through national control of production were not commercial activity. While affirming the dismissal, the court of appeals relied on the act of state doctrine rather than sovereign immunity. ${ }^{119}$ The Supreme Court denied further review. The district court's approach defined commercial activities narrowly in part "to keep the court away from areas touching closely on the sensitive nerves of foreign countries". ${ }^{120}$

A second case involved a private class action against OPEC (but not its member States). ${ }^{121}$ The complaint alleged illegal price-fixing agreements on production and export of crude oil and sought equitable relief. The complaint was sent to OPEC in Austria, but OPEC initially did not respond. Without the participation of OPEC, the district court certified a class and entered a default final judgment and injunction against OPEC. The court found that there was a conspiracy between OPEC, its Member States, and certain non-OPEC member States to fix and control crude oil prices; that the agreements coordinated and implemented by OPEC were illegal under United States antitrust laws; that OPEC's illegal conduct had resulted in substantial and adverse impact on United States trade; and that OPEC and those acting in concert with OPEC should be enjoined from entering into, implementing, and enforcing any further oil price-fixing agreements for a period of twelve months.

The district court found that OPEC was not immune because the agreements to restrict output and thereby affect prices could be performed by private persons and were thus commercial in nature. ${ }^{122}$ The court also found that OPEC, unlike its individual members, was not a foreign state or agency or instrumentality of a foreign state.

OPEC then appeared in the case and moved to vacate the default judgment and injunction on various grounds, including that the court lacked jurisdiction because OPEC had never been properly served with process. ${ }^{123}$ The district court vacated its judgment because applicable Austrian law prohibited service without OPEC's consent and later found that, in the circumstances of the case, OPEC could not be effectively served with process. On appeal, the Circuit Court affirmed the dismissal based on ineffective service and the Supreme Court denied further review.

119 Under the act of state doctrine, US courts will not adjudicate a politically sensitive dispute which would require the court to judge the legality of the sovereign act of a foreign state in its own territory. The doctrine is not jurisdictional, but rather prudential -- it deems a judicial remedy inappropriate for international comity reasons and due to domestic considerations of separation of powers of co-equal branches of government.

63 ILR at p. 291.

Prewitt Enterprises v. OPEC, 353 F.3d 916 (11th Cir. 2003), cert. denied, 543 U.S. 814 (2004)).

As in other jurisdictions, the FSIA requires US courts to consider sovereign immunity on their own motion even if the possibly immune defendant does not participate in the case.

The plaintiff attempted service on OPEC by requesting that the trial court send a copy of the complaint to OPEC by international registered mail, return receipt requested. The court clerk did so, mailing the summons and complaint to OPEC at its headquarters in Vienna. The pleadings were signed for, stamped "received" by OPEC's Administration and Human Resources Department, and forwarded to the Director of OPEC's Research Division as well as other departments including the Secretary General's office. Ultimately, the Secretary General decided that the OPEC Secretariat would initially not take any action with regard to the summons and complaint. 
The regulatory agencies do not appear to have taken significant antitrust action against foreign state entities. In testimony in 2000 to a Congressional committee, the general counsel of the FTC noted that OPEC members' actions would be highly likely to be subject to enforcement action if they were carried out by private actors. ${ }^{124}$ However, he identified some of the difficulties that such a suit would raise including difficulties in obtaining discovery (potential evidence) and in enforcing a judgment. He also noted the risk that other countries would adopt laws applicable to particular US policies. He reported that in the nearly twenty years since the IAM case had been decided, there had not been any additional antitrust challenges either to OPEC's activities or to any similar activities of foreign nations.

\section{European Union}

\section{a. $\quad$ Overview of principal available remedies and proceedings}

The competition law provisions in arts. 101 and 102 of the Treaty on the Functioning of the European Union (TFEU) (formerly arts. 81 and 82 of the EC Treaty) apply respectively to cartels and to abuse of dominant position. Regulation 1/2003 now governs competition law procedures; it replaced Regulation 17 which had applied for over 40 years. Regulation 1/2003 allows for a decentralised application of Community competition law by public authorities in member states, including national courts and competition authorities. ${ }^{125}$

While it now more decentralised, public enforcement remains the dominant form of enforcement of competition law in the EU; private enforcement remains of limited importance. Complaints to the Commission play an essential role in Community competition law; rejection of a complaint is subject to appeal to the European courts. The Commission has encouraged parties to bring actions for damages in national courts rather than present them as complaints to the Commission. Neither the Commission nor national competition authorities can award damages. Actions for damages, however, remain infrequent and efforts to remove obstacles to private enforcement are under consideration. ${ }^{126}$

Under Regulation 1/2003, the Commission has the power to impose substantial civil fines for violations of articles 101 and 102 TFEU, up to $10 \%$ of total turnover of the undertaking in the previous year. In addition, the Commission can impose periodic penalty payments not exceeding $5 \%$ of daily turnover to ensure compliance with its decisions including in some procedural matters. The Commission has published Guidelines on the Setting of Fines to clarify its policies. ${ }^{127}$ The Commission has no power to order or to seek sentences of imprisonment.

124 Testimony of William E. Kovacic, Hearing of United States Senate Subcommittee on Antitrust, Competition Policy and Consumer Rights, Committee on the Judiciary, "Crude Oil: The Source Of Higher Gas Prices?", S. Hrg. 108-604 (7 April 2004) at pp. 27-28.

125 Council Regulation (EC) No. 1/2003. Until 2003, under Regulation 17, national competition authorities, including courts, had to be empowered to apply Community competition provisions.

See Commission White Paper on Damages Actions for Breach of Community Competition Rules, $\operatorname{COM}(2008) 165$ final (2 April 2008); “Commissioner Kroes welcomes the European Parliament's crossparty support for damages for consumer and business victims of competition breaches", Memo/09/135, 26 March 2009, ("At present, there are serious obstacles in most EU Member States that discourage consumers and businesses from claiming compensation in court in private antitrust damages actions.") available at:

http://europa.eu/rapid/pressReleasesAction.do?reference=MEMO/09/135\&format=HTML\&aged=0\&langu $\underline{\text { age }=E N \& \text { guiLanguage }=\text { en }}$ 
In addition to fines, the Commission does have the power to make commitments offered by undertakings binding. This negotiated outcome allows the Commission to end a proceeding without having to decide if the competition rules were infringed. The Commission also has the power to require the undertakings and associations of undertakings concerned to bring infringements to an end. For this purpose, it may impose on them any behavioural or structural remedies which are proportionate to the infringement committed and necessary to bring the infringement effectively to an end. However, equitable type remedies are used less frequently than in the United States.

Article 23(5) of Regulation 1/2003 provides that decisions imposing fines "shall not be of a criminal law nature". ${ }^{28}$ However, the fines can be very large. The policy behind the Commission's approach to fines is generally deterrence based. In part because of the size of the fine at issue, the Commission has been required, notwithstanding art. 23(5), to provide certain fundamental rights to defendants, although the extent to which all criminal protections apply remains unclear. ${ }^{129}$ The Commission relies heavily on civil fines as its primary enforcement tool and the amounts of such fines has risen sharply in recent years (from EUR 344 million in 1990-1994 to EUR 9.4 billion from 2005-2009). ${ }^{130}$

Articles 101 and 102 TFEU apply directly to prohibit anti-competitive practices by "undertakings". ${ }^{131}$ The notion of undertaking generally includes every entity engaged in an "economic activity". In deciding whether an entity is an undertaking, the focus is on economic significance rather than legal structure or status. ${ }^{132}$ EC competition policy applies to all undertakings irrespective of whether they are publicly or privately owned. If an entity is carrying out economic activities, it will be an undertaking regardless of whether if forms part of the State administration or is a body on which the State has conferred special or exclusive rights. ${ }^{133}$

While all entities that engage in economic activities constitute undertakings, an entity, public or private, which performs tasks of a public nature, connected with the exercise of public powers or in the exercise of official authority, is not an undertaking." A distinction is thus drawn between a situation where the State acts in the "exercise of official authority" and that where it carries on economic activities of an industrial or commercial nature by offering goods or services on the market. ${ }^{134}$

128 Art. 3 and Recital 8 of the Regulation encourage the development of criminal sanctions under EU Member State law.

See, e.g., Hüls AG v. Commission, 1999 ECR I-4287, para. 150 ("given the nature of the infringements in question and the nature and degree of severity of the ensuing penalties, the principle of the presumption of innocence [from Article 6(2) of the European Convention for the Protection of Human Rights and Fundamental Freedoms] applies to the procedures relating to infringements of the competition rules applicable to undertakings that may result in the imposition of fines or periodic penalty payments"); Mannesmannrohnen-Werke AG v. Commission (T-112/98) [2001] ECR II-729.

130 For statistics on fines, see http://ec.europa.eu/competition/cartels/statistics/statistics.pdf.

$131 \quad$ See TFEU art. 101 (prohibiting specified "agreements between undertakings, decisions by associations of undertakings and concerted practices ...”); TFEU art. 102 (prohibiting specified "abuse by one or more undertakings ...").

132 See, e.g., Höfner v. Macrotron GmbH, [1991] ECR I-1979 ("the concept of an undertaking encompasses every entity engaged in an economic activity, regardless of the legal status of the entity and the way in which it is financed.").

133 Commission of the European Communities v. Italy, [1987] ECR 2599.

134 Cali \& Figli Srl v. Servizi ecologici porto de Genova SpA (SEPG), [1997] ECR I-547, para. 16; Commission v Italy [1987] ECR 2599, paragraph 7. 
A substantial number of cases involving EU member State entities have considered the distinction between "economic' activities and those where the entity "acts in the exercise of official authority" in order to decide whether the entity in question was an undertaking. In cases involving EU member state entities, the question is resolved by reference to the scope of the European treaty provisions without consideration of state immunity.

\section{b. $\quad$ Application of state immunity}

At least at first glance, the criterion for excluding an entity from being an undertaking under Community competition law - the "exercise of official authority" - appears in many respects to be similar to the concept of sovereign acts under the law of state immunity. It appears that there could be a high degree of correlation between the two concepts. To the extent that the "exercise of official authority" overlaps with sovereign acts, substantive law would be congruent with the law of state immunity. If the law does not apply as a substantive matter, state immunity as a procedural bar would not be necessary.

However, while the substantive scope may limit potential problems, it appears that state immunity issues can still arise. At least three competition law cases have considered issues of immunity with regard to non-EU state entities and international organisations.

Aluminium Imports. The European Commission rejected a claim of immunity in its 1984 Aluminium Imports decision. ${ }^{135}$ The case concerned horizontal restrictive agreements and market division agreements between, on the one hand, western European aluminium producers, and on the other hand, foreign trade organisations dealing with aluminium in the then-socialist states of Poland, Hungary, Czechoslovakia, the German Democratic Republic and the USSR. In exchange for the purchases by western producers of aluminium products from the foreign trade organisations, the latter agreed not to sell the products to other prospective purchasers in the western world. During the relevant 13-year period, the agreements had a broad effect on the market: "the operation of the agreement involved the entire primary aluminium industry of the EEC and most of that of western Europe, and involved the policing of exports to other jurisdictions including the United States and South America".

The Commission first found that the foreign trade organisations were undertakings because they engaged in trade in aluminium. Their structure was irrelevant to their status as an undertaking. It found that "[e]ntities which engage in the activity of trade are to be regarded as undertakings for the purposes of Article [81], whatever their precise status may be under the domestic law of their country of origin, and even where they are given no separate status from the State".

The Commission then rejected the claim of state immunity. It found that "the applicability of [Article 101 TFEU], since it relates to trading activities, is not defeated by claims of sovereign immunity". In using this language, the Commission was somewhat ambiguous about whether it was making a statement about the general scope of article 101 or only applying article 101 to a case involving trading activities. The Commission also noted that the domestic law of EC Member States did not accord sovereign immunity to foreign trade organizations of the type at issue.

At least some undertakings argued that the arrangements fell outside Article 101 - and that the Community should have recourse to diplomatic or retaliatory measures -- because they were acts of the 
undertakings' governments. ${ }^{136}$ The Commission rejected this argument on the facts because the governments neither signed the agreements nor obliged the undertakings to enter into them.

At least some undertakings also put forward a related argument: that the "governments concerned encouraged and supported the arrangements", which made them part of the external commercial policy of the States concerned and so not subject to scrutiny by Community institutions under Article 101 TFEU. The Commission examined the argument only with regard to the German and UK governments. The Commission recognised that from 1965 onwards the UK government gave support to UK-based undertakings to enter into certain restrictive practices.

Given the duration and scope of the restraints on the entire aluminium market, the Commission's remedy was remarkably mild. The Commission noted that it had the power to impose fines, but then stated that no fines would apply due to "special circumstances". The remedy was limited to declaring that the arrangements infringed Art. 101(1) and rejecting an exemption under Art. 101(3). The reasons for the clemency were not explained.

The decision is important in that it excluded, in the context of a proceeding that could lead to a substantial fine, the application of immunity based on the fact that the entities engaged in trade. The limitation of the remedy to declaratory relief may be at least partly explained by the state immunity and other governmental aspects to the case.

SAT Fluggesellschaft mbH v. Eurocontrol. ${ }^{137}$ This case arose from a dispute between a private German air navigation company and an international organisation. The international organisation was the European Organization for the Safety of Air Navigation ("Eurocontrol"). Eurocontrol's purpose was to strengthen cooperation between its member States (which included both EC member States and nonmember States) in the field of air navigation and develop joint activities in that field. Among other tasks, it established and collected certain route charges on users of air space.

The case arose after the private company, SAT Fluggesellschaft mbH ("SAT"), refused to pay certain route charges to Eurocontrol. Eurocontrol brought suit in the Belgian courts to recover them. In defence, SAT argued that Eurocontrol's rate-fixing procedures constituted abuse of a dominant position under art. 102 TFEU. On appeal of the case to the Belgian Cour de Cassation, the court stayed the proceedings and, under the EU preliminary ruling procedure, referred to the European Court of Justice (ECJ) a question concerning whether Eurocontrol was an undertaking within the meaning of arts. 102 and 106 TFEU. ${ }^{138}$

Eurocontrol made three immunity-related arguments to the ECJ, all of which were rejected by the Court on procedural grounds without addressing their merits. First, Eurocontrol claimed that the ECJ did not have jurisdiction in the case because of Eurocontrol's status as an international organisation. One international organisation could not judge another, relations between such organisations are governed by international law and disputes "should consequently be resolved, in accordance with general international

\footnotetext{
136 The decision does not clarify if the foreign trading organisations or only Western undertakings raised this argument.

138 Under the preliminary ruling procedure in EU law (art. 267 TFEU), national courts from EU Member States can and in some cases must refer questions of European law raised by a particular case to the ECJ for a preliminary ruling; after the ECJ responds to the request, the national court applies the law to the case.
} 
law, by recourse to arbitration". ${ }^{139}$ Eurocontrol also challenged the ECJ's jurisdiction to interpret the Eurocontrol Convention or to evaluate its conformity with EC law.

Second, for similar reasons, Eurocontrol argued that it was immune from EC rules on competition. Third, Eurocontrol argued that any judgement subjecting Eurocontrol to EC competition law could not be enforced because the judgment would not bind non-EC member States that were member States of Eurocontrol. Any changes that EC competition law might require to Eurocontrol's rules could only be adopted unanimously by all Eurocontrol Contracting States, including non-EC member States that would not be bound by the ECJ judgement.

The ECJ rejected Eurocontrol's arguments on procedural grounds without addressing their merits. The Court relied on the specific nature of the preliminary ruling procedure under EC law. It found that procedure a non-contentious one solely between national courts and the ECJ and that initiatives by the parties to the main proceeding were excluded. ${ }^{140}$ Eurocontrol's alleged immunity from EC competition law did not need to be addressed because "[t]he question whether the rules of Community law may be relied upon as against Eurocontrol is connected with the substance of the case and has no bearing on the jurisdiction of the Court". The alleged inability to enforce the judgment was also connected with the substance "in that it presupposes that the question whether Eurocontrol constitutes an undertaking subject to rules of competition has been resolved".

As a matter of substantive EC law, the ECJ found that Eurocontrol was not an undertaking. It found that Eurocontrol carried out, on behalf of its member States, tasks in the public interest aimed at contributing to the maintenance and improvement of air navigation safety. The specific acts in question in the underlying litigation, the collection of route charges, were not separable from Eurocontrol's other activities and the applicable rates resulted in reality from decisions by Eurocontrol's member States. Accordingly, taken as a whole, Eurocontrol's activities were typically those of a public authority and were not of an economic nature.

In contrast to the narrow procedural ruling of the Court on the immunity-related issues, the opinion of the Advocate-General (presented to the Court prior to its decision) addressed some of those issues on the merits and advocated that the Court reject the claimed immunity. ${ }^{141}$ The Advocate-General agreed with the Commission that if Eurocontrol were an undertaking by virtue of its operations, "there [was] no reason why [art. 101 TFEU] should not apply to it merely because it is an international organisation". He noted that the ECJ's case law on the notion of undertaking gave priority to economic considerations over strictly legal ones although he referred only to cases involving EU member State entities. While different views existed about the scope of immunity of international organisations, the notion of absolute immunity should be rejected, particularly because even State immunity is no longer absolute. The rights of private parties could be impaired by an absolute theory.

139 There is no general system of arbitration for international law disputes and any arbitration could only occur by agreement of both parties. The opinion does not clarify if such an agreement existed or if Eurocontrol was perhaps offering to submit the dispute to arbitration.

141 ECJ procedures also provide for an Advocate-General opinion to the Court in most cases. The AdvocateGeneral is a member of the Court, but does not participate in the deliberations of the Court. He/she participates publicly in the process leading up to decision. He/she is not a public prosecutor and is not subject to any authority. The Advocate-General's submissions are presented at the end of the oral proceedings. They do not reflect the Court's views but they are reported together with the case and often provide important background information. 
While the Advocate-General rejected an absolute theory of immunity, his opinion did not then specifically address whether the Eurocontrol activities at issue were immune or not under a restrictive theory.

The lack of analysis of whether Eurocontrol's actual activities were immune under a restrictive theory is noteworthy because the opinion does analyse, in the context of deciding whether Eurocontrol was an undertaking, the arguably similar question of whether the activities constituted "economic" activities or whether they involved the "exercise of official powers". And the Advocate-General's criterion to resolve this competition law question practically restates an approach frequently used in the law of state immunity: "it is apparent that the essential factor in classifying a body as an undertaking is the pursuit of an economic activity capable of being carried on, at least in principle, by a private undertaking with a view to profit."

The Advocate-General's decision not to apply the restrictive immunity approach to the facts may be explained by the fact that Eurocontrol apparently relied only on an absolute theory. However, it is generally recognised that, at least with regard to foreign States, courts should determine issues of immunity on their own initiative where necessary. ${ }^{142}$ The Advocate-General's views on the application of restrictive immunity would have provided more insight into the relationship between substantive competition law and immunity. ${ }^{143}$

As noted, the ECJ's decision did not follow the Advocate-General in addressing immunity on the merits. It found that all of the immunity-related issues were issues of substance for the Belgian court. The finding that immunity falls outside of the scope of the preliminary reference procedure and is thus an issue for the national courts of EU member States may have important consequences, especially if private suits in those courts based on EU competition law become more prevalent.

Even if the court had found that Eurocontrol's activities were such as to benefit from immunity, it would likely have been found to have waived its immunity. Where a State brings a lawsuit itself as plaintiff, it is generally considered to have waived its immunity. ${ }^{144}$

Selex v EC Commission and Eurocontrol. A second competition law case involving Eurocontrol and its potential immunity arose in the different procedural context of a complaint to the Commission. The Commission addressed the issue and excluded immunity, but on appeal the European courts again found that the immunity question was not properly presented to them for decision.

The case arose from a 1997 complaint to the European Commission about Eurocontrol by Selex Sistemi Integrati SpA (Selex), a private company that operates air traffic management systems. Selex alleged that Eurocontrol was abusing a dominant position and distorting competition in the market for air traffic management systems. ${ }^{145}$ In 1999, Eurocontrol responded to the Commission with regard to the complaint and raised the sovereign immunity plea.

142 See, e.g., UNCSI Art. 6(1) ("A State ... shall ensure that its courts determine on their own initiative that the immunity of [the foreign] State ... is respected.).

On Eurocontrol's argument that the Court lacked jurisdiction, the Advocate-General rejected the argument on the same procedural grounds that the Court relied on, ie., the nature of the preliminary ruling procedure.

See, e.g., UNCSI Art. 8(1) ("A State cannot invoke immunity from jurisdiction in a proceeding before a court of another State if it has: (a) itself instituted the proceeding;"). The Advocate-General noted that jurisdictional arguments such as those made by Eurocontrol are generally made by defendants whereas Eurocontrol was the plaintiff in the underlying proceeding. Eurocontrol, for the development and acquisition of prototypes of new systems and equipment for 
Whereas in SAT, Eurocontrol was a civil plaintiff seeking damages and the competition law point was raised by a private party as a defence to liability to Eurocontrol, in Selex it was the target of a complaint, which if accepted, could lead to the Commission imposing substantial civil fines for abuse of dominant position.

The Commission rejected the complaint in 2004, finding that as a matter of substantive competition law, Eurocontrol was not an undertaking. ${ }^{146}$ It relied on the ECJ's substantive holding in SAT that Eurocontrol's activities were in the exercise of official authority.

Before addressing the substantive law, however, the Commission rejected Eurocontrol's immunity claim that it was not subject to EC competition law. It noted that the ECJ had discussed the application of EC competition law to Eurocontrol in SAT when it found that Eurocontrol was not an undertaking.

It then referred to the need, ostensibly for purposes of a "full exposition of the ECJ's position" in SAT ["per una completa disamina della posizione assunta dalla Corte di Giustizia"], to refer to the AdvocateGeneral's opinion. The Commission quoted the Advocate-General's statement in SAT that if Eurocontrol were an undertaking by virtue of its operations, "there [was] no reason why [art. 101 TFEU] should not apply to it merely because it is an international organisation". ${ }^{147}$ Relying in addition on the ECJ case law finding that the notion of undertaking does not take account of structure or status, it then concluded that it was "evident that EC rules on competition can apply to international organisations".

Once it made this general finding, the Commission ended its inquiry into immunity. It turned directly from this general conclusion to the question of whether Eurocontrol was an undertaking.

The Commission's approach to immunity is thus even more succinct than that of the AdvocateGeneral in SAT. As noted above, the Advocate-General's opinion excluded absolute immunity in favour of restrictive immunity, but then did not address the question of the application of restrictive immunity to Eurocontrol's activities. The Commission's decision in Selex simply concludes that competition law can apply and immediately turns to the substantive law question of whether the international organisation was an undertaking. The Commission evidently rejected absolute immunity, but did not indicate whether it considered that international organisations are subject to a restrictive theory of immunity, or whether they are not immune at all.

The absence of any reference to restrictive immunity meant that, as in the Advocate-General's opinion in $S A T$, the reasons leading to a finding that Eurocontrol was engaged in "acts in the exercise of official authority" (and was therefore not an undertaking) were not considered with regard to whether they might also justify immunity under a restrictive theory of immunity.

applications in the field of air traffic management was liable to create de facto monopolies in the production of systems which are subsequently standardised by that organisation. In addition, the complaint stated that, as a result of assistance provided by Eurocontrol to national administrations, at the latters' request, undertakings which had supplied prototypes were in a particularly advantageous position as compared with their competitors in tendering procedures organised by national authorities seeking to acquire equipment.

146 See Decision of European Commission, Pratica No F-1/36.751 Alenia/Eurocontrol (12 February 2004), available (in Italian only) at http://ec.europa.eu/competition/antitrust/cases/decisions/36751/it.pdf (web publication for information only; non-confidential version). Selex was the successor-in-interest to Alenia.

The Commission's claim that it was relying on the authority of the ECJ decision in SAT appears to be weak because, as noted above, the ECJ expressly declined to address the immunity questions in $S A T$ and found that all three of the immunity-related issues were for the Belgian court to decide. 
The Commission's view that immunity should not interfere with the scope of EU competition law is evident, but its exact legal position remains unclear. On its face, it could be read as implicitly excluding immunity considerations from competition law, at least for international organisations; the sole issue to be decided is whether the entity is an undertaking as a matter of substantive law. This interpretation would go beyond the Advocate-General's position in SAT. If applied to a State engaged in sovereign acts, it could raise issues under the customary international law of immunity particularly if a proceeding resulted in a substantial fine.

Alternatively, the Commission's decision could perhaps be read as an implicit decision that the definition of undertaking is congruent with the restrictive theory of immunity. This is also one possible reading of the decision in Aluminium Imports. ${ }^{148}$ This theory can perhaps remain implicit in cases where liability is excluded on substantive grounds, as in Selex. But congruence could need to be demonstrated more thoroughly if liability were to be imposed based on a finding that a State were an undertaking.

Selex unsuccessfully appealed the rejection of its complaint to both European Court of First Instance (CFI) and subsequently to the ECJ. ${ }^{149}$ Eurocontrol was permitted to intervene in both proceedings and raised its immunity arguments.

Both the CFI and the ECJ rejected the immunity arguments on procedural grounds, finding them to be inadmissible arguments from an intervener. The court found that acceptance of the plea of immunity would render the contested decision unlawful. This could lead to it being annulled, but not to the action being dismissed as requested by the Commission. The intervener's attempt to obtain different relief from that sought by the parties was contrary to the procedural limitations on the role of interveners. Eurocontrol also argued that the ECJ should consider the immunity issues on its own motion, but the ECJ found it had no need to do so.

\section{The UK government decision to require partial divestment of a Kuwaiti investment in British Petroleum}

During the autumn and winter of 1987-88 Kuwaiti State-controlled interests acquired a holding of shares of The British Petroleum Co plc (BP) amounting to some 21.6 per cent of its issued ordinary share capital. At the time, it was understood and the matter was evaluated on the basis that the purchases were made by KIO, an integral part of the Kuwaiti State.

On 3 May 1988 the Secretary of State for Trade and Industry required the Monopolies and Mergers Commission (MMC) to investigate and report on whether a "merger situation" had been created and, if so, whether it operated or may be expected to operate against the public interest. ${ }^{150}$ Under applicable law, the decision about the matter was then for the Minister.

Under applicable law, a merger situation would be created if the holding gave the Government of Kuwait the ability materially to influence the policy of BP. The MMC concluded that the Government of

\footnotetext{
148 While the result was consistent with the outcome in Aluminium Imports, the Commission did not cite its earlier decision.

149 See Selex Sistemi Integrati SpA v. Commission of the European Communities and Organisation européenne pour la sécurité de la navigation aérienne (Eurocontrol), Judgment of the ECJ (Second Chamber), Case C-113/07 P (26 March 2009) \& Opinion of Advocate-General Trstenjak (3 July 2008).
}

This section of the paper relies generally on the 1988 report of the UK Monopolies and Mergers

Commission, The Government of Kuwait and British Petroleum Company plc: A Report on the Merger

Situation, available at

http://www.competition-commission.org.uk/rep_pub/reports/1988/231kuwaitbp.htm\#full. 
Kuwait's holding gave it the ability materially to influence the policy of BP. It relied on the fact that BP's share capital was very widely held. At 21.6 per cent the holding by the Government of Kuwait dwarfed all others, the next largest individual beneficial holdings being the 1.8 percent held by the Prudential Corporation and 1.7 per cent held by the UK government. Votes represented by proxies given at BP's general meetings generally ranged between 12 and 14 per cent of its issued share capital.

The MMC report concluded that the investment was not in the public interest. In coming to this conclusion, the Commission took into consideration, amongst other matters, the areas of potential conflict of interest over the long term between the State of Kuwait on the one hand and BP and the United Kingdom on the other hand.

It noted that unlike other shareholders Kuwait is a sovereign state with wide strategic and political interests and could be expected to exercise its influence in support of its own national interest. This would be to the detriment of BP's interests and to the United Kingdom's public interest.

Among the factors taken into account by the Commission were:

(a) the strategic and economic importance of oil and its place in the fluctuating relations between the West, including the United Kingdom, and the states of the Middle East which results in a basic conflict of interest between the countries of the Gulf with vast reserves of oil that are and will remain cheap to extract and oil-consuming countries including those with dwindling reserves of oil that will become more difficult and costly to extract; and

(b) the likelihood of future conflicts of interest on matters such as the exploration and development of new production facilities for oil; research and development including the development of substitute sources of energy or oil products; and downstream acquisition policy.

Kuwait made a number of undertakings during the MMC process and late in the process, sought to formalise them in a deed of covenant between Kuwait and the Secretary of State for Industry. In the deed, Kuwait notably covenanted to hold its investment for investment purposes only and not to seek to further Kuwaiti State interests other than its interests as an investor. It also covenanted not to increase its holdings further, not to seek representation on the board and to limit its voting rights to $14.9 \%$. The deed waived the state immunity of Kuwait and its agencies for any action to enforce the deed by way of injunction or order for specific performance.

The Secretary of State did not recognise the deed so that it apparently remained as an offer from Kuwait to enter into such a deed. The MMC did not find the deed covenants to be sufficient to overcome its concerns about the public interest, finding that a $14.9 \%$ voting interest would still allow Kuwait exert a material influence. The MMC also expressed concerns about the enforceability of the covenants.

The report was transmitted to the Secretary of State for Industry for consideration. Early in October 1988, the British government required KIO to reduce its holding to $9.9 \%$ within a year. After protests from KIO that grace period was increased to three years. It appears that the voting rights of the shares were limited to $9.9 \%$ during the grace period.

The law in this case required that any decision be taken by the government (on the basis of a report from a regulatory agency) rather than by a court or regulator directly. It thus falls outside of the scope of state immunity as a doctrine applicable to decisions by the courts. Nonetheless, it provides an important precedent for the application of broad competition law principles to a foreign state investment.

Neither Kuwait nor KIO sought to challenge the government decision in court. KIO was apparently able to dispose of the interest in excess of $9.9 \%$ at a significant profit due in part to its immunity from tax 
as a foreign state. BP ultimately bought back the shares and KIO received a substantial refund of withholding tax. As noted above in the section on tax, evidence subsequently emerged that the owner of the shares had been the Kuwait Petroleum Corporation, a company not entitled to a tax exemption under UK law, which led to an Inland Revenue investigation.

The analysis of the MMC was based on the understanding that the shares were owned by Kuwait through KIO. The competition law aspects would have been significantly modified if it had been understood that the shares were owned by KPC, a direct competitor of BP; for example, a stronger divestment order might have been recommended. In addition, this possible aspect also illustrates the procedural difficulties that may arise in obtaining information from foreign state entities that is necessary for solid regulatory analysis. It does not appear that the exact ownership was ever determined in a public decision and it is unclear whether any possible actions were considered or taken with regard to what may have been possible misrepresentations to a regulatory body. ${ }^{151}$

151 A Spanish news report indicated that similar issues may have arisen with regard to information supplied to regulators in connection with foreign investment review of KIA/KIO's investments in Spain. See KIO ocultó datos básicos sobre el origen de su capital al rellenar los impresos de Economía, El País (11 March 1994). 


\section{GENERAL CONSIDERATIONS ON THE APPLICATION OF REGULATION TO FOREIGN STATE-CONTROLLED ENTITIES}

For a number of reasons, it is difficult to draw general conclusions about foreign state immunity from host state regulation. First, state immunity from regulation has generally been the subject of even less attention than immunity from criminal law. For example, whereas criminal law, as noted above, is at least explicitly or clearly excluded from conventions governing state immunity, regulation is not always specifically or fully addressed.

The ECSI does directly exclude certain regulatory proceedings from its scope. The Explanatory Report to the ECSI ( $\S 12$ ) notes that "[t]he Convention does not cover the problem of immunity in proceedings before administrative authorities of another State".

The scope of the UNCSI is less clear. There is no provision addressing administrative proceedings or cases brought by public agencies. However, as noted above in the section on tax, the argument for removal of a draft provision addressing immunity from tax from an early ILC draft convention was that such a provision addressed State-to-State proceedings whereas the UNCSI addressed cases brought by private parties. This places the emphasis principally on the question of whether a regulator is bringing the proceeding. This appears to be the basis of the view advanced that the UNCSI "relates only to commercial and private law matters". ${ }^{152}$

Second, state practice is scarce and inconsistent and as a result customary international law is difficult to define. National legislation on state immunity generally does not address regulation as such. State practice in the area of tax and competition law provides some background but few answers. In the area of tax, review of the policies of countries that all apply the restrictive theory to private law cases reveals that they apply different approaches to immunity from tax. In the area of competition law, regulators have generally contended that the law is applicable to foreign State-owned companies or even foreign States, but have not attempted to address the rationale or possible limits that may be applicable. Nor have they brought many cases. The courts have frequently found it possible to avoid addressing the issue of immunity based on a variety of procedural or jurisdictional findings. No case appears to have sanctioned a foreign state. Commentary on customary international law in this area is also scarce.

One approach to addressing regulation is to consider it by reference to criminal law. Fox arguably takes this approach in appearing to define criminal conduct for purposes of state immunity in broad terms as "the contravention of the public law of the State". ${ }^{153}$ This approach would appear to group regulation together with criminal law.

The Australian Law Reform Commission report also appeared to consider that regulatory legislation raised similar issues to criminal law and that neither could be subject to any general formula. Both had to be resolved primarily between the relevant governments or agencies and the foreign state in question. It recommended the exclusion of both from the proposed statute governing state immunity:

\footnotetext{
152 Hazel Fox, "In Defence of State Immunity: Why the UN Convention on State Immunity is Important", 55 ICLQ 399, 405 (2006). 
All the recent overseas legislation applies only to civil proceedings; criminal matters are specifically excluded. It is recommended that the some position be taken in the Australian legislation. Problems arising with the application of penal or regulatory legislation to foreign states cannot be resolved through the application of any general formula, but depend on the particular legislation in question. They are also matters which do not directly affect civil rights, and which have to be resolved primarily between the relevant governments or agencies and the foreign state in question. ${ }^{154}$

As the Law Commission notes, however, it seems doubtful that any general formula could apply to a category as broad as regulatory legislation. Regulation is perhaps best analysed in functional terms on a sliding scale depending on a number of factors which would affect the strength of the case for applying a restrictive theory of immunity (or otherwise limiting immunity). Some of these are similar to those noted above as supportive of a possible application of restrictive immunity in criminal proceedings.

Remedies to be applied. Perhaps the most important factor is whether the remedies at issue are compensatory or punitive in nature. The functional importance of remedies is illustrated by the ECSI. In order to overcome concerns about the difficulty of defining public and private law, the scope of the ECSI is defined directly by reference to types of remedies at issue. The commentary notes that "[c]ustoms duties, taxes, penalties and fines have been excluded because in some countries they do not fall exclusively under public law or because the dividing line between public and private law is ill-defined or non-existent."

Although it involves a different question, case law addressing whether particular regulatory proceedings should be considered to be criminal for purposes of attracting the procedural protections of Art. 6 of the ECHR may also be instructive. Factors considered in ECHR cases include the classification in domestic law, the nature of the provision in question, the purpose of the penalty and the nature and the severity of the penalty. The classification of the measure under domestic law is a factor, but is not conclusive.

The public nature of the enforcement agency. The initiation and conduct of regulatory enforcement is generally within the control of the government of the forum state (broadly construed). It can decide whether to investigate, prosecute or bring enforcement action. Courts may tend to defer to what they may see as a decision by the executive, in effect finding that it has taken the responsibility for making the determination about the appropriateness of the proceeding. Of course, some regulatory agencies may have substantial independence from the national executive power. This factor is also probably of differing importance in various jurisdictions depending on their institutional structure and the remedies at issue. For example, regulatory agencies that bring what are in effect claims for compensation on behalf of private parties may not raise significant issues and the claims may be subject to the same restrictive approach to immunity as if the case were brought by the private parties themselves.

Applicable definition of the foreign state and type of foreign state entity at issue. As noted above, there are different approaches to defining the foreign state notably with regard to SOEs. Many countries do not consider independent SOEs to be part of the foreign state and they are subject to the law in the same manner as private entities. For jurisdictions like the US that include a significant number of SOEs as part of the broader foreign state, application of absolute immunity to all of the broader foreign state would accentuate differences in treatment of SOEs. If a case involves an independent SOE that is considered to be part of the broader foreign state by forum state law but would be treated as a private entity by many other

\footnotetext{
154 Australia Law Reform Commission Report No. 24 "Foreign State Immunity", (1984) para. 161.

155 ECSI Commentary para. 113.
} 
jurisdictions, the rationale for application of the restrictive approach to immunity of the SOE, even in a regulatory context, is much stronger.

Clearly commercial acts. An underlying transaction of a clearly commercial nature would strengthen the case for excluding immunity. Here it would be important for the law concerning the commercial nature of SWF activities to be as clear as possible. If for matters of private law the courts are finding that SWF investments are sovereign rather than commercial, it could be difficult for the recipient state to exclude immunity for purposes of regulation. As noted above, the limited existing case law suggests that it could be difficult to achieve through court decisions a consensus view that SWF investment activities are commercial for purposes of immunity.

Strength of contacts with the forum state. Another factor, as noted by Fox, is the strength of the contacts of the case, including the territorial contacts, with the forum state. A strong jurisdictional (territorial) connection of the events with the forum state gives that state a strong interest in the matter and can limit concerns about interfering in the internal affairs of another state. A strong territorial connection would normally exist with regard to SWF investments in the recipient forum although in some cases the actions at issue would occur where the fund is managed which could be in its home state or a third state financial centre.

This list is merely illustrative and much will depend on the facts in each case. In light of the rarity of cases in this area, a major case that may illustrate the application of some of these considerations in practice, in particular with regard to remedies, is reviewed in Annex 1. 


\section{ANNEX 1 \\ Immunity issues and the selection of remedies in a major financial case involving simultaneous criminal, regulatory and civil actions}

State immunity played a role in the civil cases and may have played some role in the criminal and administrative proceedings against Credit Lyonnais and other entities and individuals arising out of the acquisition of junk bonds and the insurance business of the failed Executive Life Insurance Company of California. A full description and analysis of this complex case is beyond the scope of this note, but a brief summary may provide some insight into the importance of remedies in a major financial case.

The underlying facts (as summarised in the US Department of Justice press release accompanying the plea agreements of Crédit Lyonnais and certain related entities in December 2003) were as follows:

Executive Life, which was once the largest life insurance company in California, held a multibillion dollar portfolio of "junk bonds." In 1991, Executive Life was declared insolvent and was seized by the California Department of Insurance. As part of the rehabilitation of Executive Life, both its insurance business and its junk bond portfolio were put up for sale. Credit Lyonnais, through its investment banking subsidiary Altus Finance S.A., orchestrated a scheme in which it obtained Executive Life's bond portfolio, and used secret "parking" agreements - referred to in French as portage agreements - to gain illegal control of Aurora National Life Assurance Company, a newly formed California life insurance company that acquired the restructured Executive Life insurance business. These secret portage agreements, and Credit Lyonnais' resulting illegal control of the insurance business, remained concealed until the fraud came to light in the summer of 1998 when an anonymous whistleblower alerted California authorities of their existence.

The state immunity aspects arose because of the evolving ownership structure of Crédit Lyonnais and related entities. Crédit Lyonnais (as well as its Altus subsidiary) were State-owned at the time of the 19911992 Executive Life acquisition. In the mid-1990s, however, the French government intervened to rescue Crédit Lyonnais from impending financial failure. To this end, the government created Consortium de Réalisation (CDR), a defeasance corporation (similar to the US Resolution Trust Corporation), to which the government transferred certain assets and liabilities of Credit Lyonnais for orderly liquidation. ${ }^{156}$ As of 2002, CDR's shares were wholly owned by the Établissement Public de Financement et de Restructuration, a public administrative body and arm of the French State. CDR, in turn, had several wholly-owned subsidiaries, including CDR-Entreprises (CDR-E), which owned and managed for purposes of defeasance certain industrial interests formerly owned by Crédit Lyonnais. ${ }^{157}$

\footnotetext{
156 These defeasance structures are often referred to more colloquially as "bad banks" because their role is to relieve the existing bank of liabilities and/or poor quality assets, and liquidate them at public expense. CDR-E and Crédit Lyonnais with the support of the French government. See Brief Amicus Curiae of Consortium de Réalisation, CDR Entreprises and Credit Lyonnais, S.A. in Support of Petitioners at p. 1-3 (filed 23 August 2002), Dole Food Co. v. Patrickson, 538 US 468 (2003).
} 
By 2002, civil suits relating to Executive Life had been filed against CDR, CDR-E (which was alleged to be the successor in interest of Crédit Lyonnais's Altus subsidiary) and Credit Lyonnais (which was privatised in 1999 after being relieved of its crippling liabilities). Those entities had invoked their status as a agency or instrumentality of a foreign state to remove the civil suits from state court to federal court under the FSIA.

The Dole case then-pending before the Supreme Court, however, raised two state immunity issues of direct relevance to the status of CDR, CDR-E and Credit Lyonnais: the status under the FSIA, as agencies or instrumentalities of the foreign state, of (i) indirectly-held companies; or (ii) companies privatised as of the date of the complaint. CDR-E was indirectly-held and Credit Lyonnais had been privatised in 1999. In 2002 CDR, CDR-E and Credit Lyonnais, with the support of the Republic of France, filed an amicus brief with the Court in Dole on the two issues in that case. As noted above, the Supreme Court found in Dole that the requirement, for an entity to be an agency or instrumentality, that a "majority of [the] shares [be] owned by a foreign state" was satisfied neither by indirectly-held companies nor by companies privatised as of the date of the complaint.

Dole was a civil case under the FSIA and did not address criminal cases. Nonetheless, it is noteworthy that the criminal case against CDR-E and Credit Lyonnais was not filed until late 2003 after Dole was decided.

The structure of the settlement was confidentially negotiated and it is impossible to determine the role played by claims or recognition of state immunity in the way it which it was structured. Nonetheless, the settlement structure has some interesting features when viewed from the perspective of state immunity and remedies available to regulatory agencies.

Credit Lyonnais and CDR-E each pled guilty to three felony counts of making false statements to the Federal Reserve Board. Credit Lyonnais, the privatised company, paid a USD 100 million criminal fine. To resolve a parallel Federal Reserve Board administrative proceeding that was part of the global settlement, it also paid an additional USD 100 million civil penalty imposed by the Federal Reserve and agreed to a Federal Reserve cease and desist order (an order similar to an injunction) designed to prevent future violations by Credit Lyonnais of the federal Bank Holding Company Act. ${ }^{158}$

CDR-E, the indirectly State-owned company, did not pay a fine or a civil money penalty. It paid USD 375 million in compensatory damages (into a settlement fund available to the California Insurance Commissioner for distribution to former Executive Life policyholders to compensate them for lost benefits; the funds were to be held in reserve pending the outcome of a civil lawsuit previously filed by the Commissioner).

158 The Federal Reserve has publicly disclosed its interpretation of relevant statutes with regard to their application to foreign states and foreign state-controlled entities. For example, it has interpreted the Bank Holding Company Act (which applies to require Federal Reserve approval of certain investments in investors in U.S. banks and bank holding companies) to apply to investments by companies controlled by a foreign government, but not to the foreign government itself. See http://www.federalreserve.gov/newsevents/testimony/alvarez20080424a.htm (testimony by Federal Reserve general counsel, Scott Alvarez, on the circumstances under which the Federal Reserve would have jurisdiction over sovereign wealth funds) (24 April 2008). The Federal Reserve has taken public regulatory enforcement action against foreign-government-owned banks that operate in the United States including State Bank of India 2001, 1994 and Banco Industrial de Venezuela 2005, 2006. 
It is noteworthy that the remedies applied to CDR-E, the State-owned entity, are compensatory in nature, while those applied to the privatised Crédit Lyonnais are punitive but of a lesser amount. Although both CDR-E and Credit Lyonnais pled guilty to three felony counts of making false statements to the Federal Reserve, the Federal Reserve did not impose any sanctions against CDR-E. CDR, which was owned by an arm of the French State, was not named in the charging document (the criminal information) although it was a defendant in the civil suit brought by the California Insurance Commissioner. ${ }^{159}$

159 The civil suit by the California Insurance Commissioner seeking damages against CDR, CDR-E and Crédit Lyonnais was settled by a substantial cash payment in 2005. 